\title{
Climate change adaptation in and through agroforestry: four decades of research initiated by Peter Huxley
}

\author{
Meine van Noordwijk ${ }^{1,2}$ (D) $\cdot$ Richard Coe $^{1} \cdot$ Fergus L. Sinclair $^{1,3}$ (D) Eike Luedeling ${ }^{4}$ (D) \\ Jules Bayala ${ }^{1}$ - Catherine W. Muthuri ${ }^{1}$ - Peter Cooper ${ }^{5} \cdot$ Roeland Kindt $^{1}$ (D) . \\ Lalisa Duguma ${ }^{1} \cdot$ Christine Lamanna $^{1}$. Peter A. Minang ${ }^{1}$
}

Received: 4 March 2020 / Accepted: 28 April 2021 / Published online: 9 June 2021

(c) The Author(s) 2021

\begin{abstract}
Agroforestry (AF)-based adaptation to global climate change can consist of (1) reversal of negative trends in diverse tree cover as generic portfolio risk management strategy; (2) targeted, strategic, shift in resource capture (e.g. light, water) to adjust to changing conditions (e.g. lower or more variable rainfall, higher temperatures); (3) vegetation-based influences on rainfall patterns; or (4) adaptive, tactical, management of tree-crop interactions based on weather forecasts for the (next) growing season. Forty years ago, a tree physiological research tradition in aboveground and belowground resource capture was established with questions and methods on climate-tree-soil-crop interactions in space and time that are still relevant for today's challenges. After summarising early research contributions, we review recent literature to assess current levels of uncertainty in climate adaptation assessments in and through AF. Quantification of microclimate within and around tree canopies showed a gap between standard climate station data (designed to avoid tree influences) and the actual climate in which crop and tree meristems or livestock operates in real-world AF. Where global scenario modelling of 'macroclimate' change in mean annual rainfall and temperature extrapolates from climate station conditions in past decades, it ignores microclimate effects of trees. There still is a shortage of long-term phenology records to analyse tree biological responses across a wide range of species to climate variability, especially where flowering and pollination matter. Physiological understanding can complement farmer knowledge and help guide policy decisions that allow AF solutions to emerge and tree germplasm to be adjusted for the growing conditions expected over the lifetime of a tree.
\end{abstract}

Keywords Agroecology $\cdot$ Agroforestry models · Climate shift · Multipurpose trees · Resilience $\cdot$ Tree architecture

Dedicated to a celebration of the contributions the late Peter A Huxley (1926-2019) and Chin K. Ong (1948-2020) made to agroforestry research.

Meine van Noordwijk

M.vannoordwijk@cgiar.org

Extended author information available on the last page of the article 


\section{Introduction}

Global circulation models (or ensembles of such models), parameterised for a range of policy-relevant and credible greenhouse gas emission scenarios, project how temperature will increase and how rainfall, depending on location, will either increase or decrease in the coming decades (Pachauri et al. 2014). Although the land use sector can contribute to a world where global warming is capped at $1.5^{\circ} \mathrm{C}$ (Roe et al. 2019), the global cohesiveness and political will needed to achieve that is lacking. With current crops and cropping patterns, without adaptation, ongoing and expected climate change challenges food supply (Smit and Skinner 2002; Fischer et al. 2002, 2005; Schmidhuber and Tubiello 2007). The predominant narrative on how agriculture should adapt to these changes is through major crop improvement programmes, supported by new genomics and gene-level change, that generate the new crop varieties with greater tolerance to drought and high temperatures, especially for the primary staple crops (Burke et al. 2009; Varshney et al. 2011; Dempewolf et al. 2014). Next to emission reduction ('mitigation'), this type of climate change adaptation is advocated as the main way to avoid global food insecurity in the future (Porter et al. 2014). Agricultural adaptation strategies suggest that farmers substitute crops, explore alternative livelihood strategies or relocate (Rippke et al. 2016), but do not think of modifying local climate by tree planting. Yet, that is what evidence shows they might do, outside the purview of mainstream research.

Recent advances in agroecology and agroforestry research (Sinclair et al. 2019; van Noordwijk 2019a, b, c; van Noordwijk et al. 2019a, b, c, d) bring important nuances and challenges to this narrative in the following four main ways that will be the entry points to this literature review.

A. Long-term persistence of AF systems in fragile environments such as Sahelian or Mediterranean drylands is based on maintenance of the buffer functions trees and soils protected by trees provide (Bayala et al. 2019b). The crop-level microclimate in any location is modified and modifiable by a change in tree cover from what climate station data and the models that are calibrated on such data (van Noordwijk et al. 2013, 2014) project. The temperature range of microclimatic effects of trees so far exceeds global warming (Ovalle-Rivera et al. 2015), whilst rainfall dependence on continental land cover may involve a 10-20\% shift (increase with more upwind tree cover, decrease with upwind deforestation) in many areas relevant for agricultural production (Ellison et al. 2019). Rather than taking projected local climate change as a given (only actionable via global emission control), there is scope for local and regional actions, focusing on the water balance and hydroclimatic relations (Robiglio et al. 2017; Creed and van Noordwijk 2018), as is increasingly done in managing the cooling services provided by urban trees (Pretzsch et al. 2021).

B. Climate change is mostly climate shift, with the change in local suitability of crops and crop varieties likely to have existing solutions in adjacent or, sometimes distant, 'climate analogues' (where current climate is similar to what is projected for a target location) (Bos et al. 2015). A focus on social learning, germplasm exchange and social-ecological system governance may be more relevant than (or at least complement) crop breeding and 'tree improvement' (Sinclair et al. 2019). Given the large number of trees and the low degree of genetic 'domestication' of most species used, tree adaptation research is mostly through a combination of tree-site matching, supported by geographic informa- 
tion systems, attention to local ethnobotanical knowledge and germplasm exchange and hence the consideration of whole system adaptation responses rather than focussing on only one component (Kmoch et al. 2018).

C. Tree diversity with potential relevance for AF varies over at least three orders of magnitude $(1-10,10-100,100-1000$ species in the regional tree species pools from which AF recruits its trees) depending on location (van Noordwijk et al. 2019a). Tree-site matching research has shown wide ranges of climatic tolerance and phenotypic adjustments of aboveground and belowground morphology, with opportunistic and episodic fruit and seed production as apparently adaptive traits (Huxley 1999a). Phenology data (as scarce as they are) has documented a wide range of species-level and individual variation, with differential access to landscape-level water reserves as a likely contributor (Do et al. 2005; Valdez-Hernández et al. 2010). This lack of predictability is a problem where regular production for established market channels is the norm, creating 'needs' for horticultural management (irrigation, drainage, fertilisation, pruning) (Goldschmidt 2013). In the genotype-environment-management interaction, aspects other than global climate change are likely to dominate (van Noordwijk et al. 2019b). Elsewhere, especially in high tree-diversity environments or where the focus is on wood or resins, variability in individual tree-level performance is less of an issue, and portfolio risk management under uncertainty (using principles documented for crop diversity, van Noordwijk et al. 1994) is the primary line of defence (Ordoñez et al. 2014).

D. The conventional view of the development trajectory for agriculture, namely a general trend of simplification, specialisation and increased inputs, is challenged by agroecology (Altieri and Nicholls 2017; HLPE 2019). The alternative of complexity, diversity and recycling, that includes trees and $\mathrm{AF}$, has been shown to increase resilience to climate change in specific contexts, but its widespread adoption is likely to be constrained by market failures, maladapted policies and the paucity of evidence about the performance of agroecological practices across contexts that 'locks-in' industrial models of agricultural improvement and adaptation (Sinclair et al. 2019).

These four challenges to a 'business as usual' model of agricultural development in response to the climate change challenges call for a multi-pronged approach to policy and practice for adapting agricultural and food systems to global climate change. It may have to go beyond what current 'climate-smart' approaches to agriculture set out to achieve (McCarthy et al. 2011; Carter et al. 2018; Kimaro et al. 2019; Rosenstock et al. 2019b), and build on earlier ideas of AF at the interface of climate change adaptation and mitigation (Verchot et al. 2007; Schoeneberger et al. 2012). A new appreciation of the relevance of $\mathrm{AF}$ and related practices for the climate change agenda is emerging as part of the recent IPCC land-use report (IPCC, 2019; Smith et al. 2019). The 2019 update of the IPCC guidelines for national greenhouse gas inventories for the first time explicitly includes default data (for Tier 2 accounting) for a range of AF land uses (Cardinael et al. 2018; Ogle et al. 2019). National Adaptation Plans increasingly make explicit reference to agroforestry (Meybeck et al. 2020).

The wide diversity of extant AF practices across the (sub)tropics (Nair 1993; Beer et al. 1987; van Noordwijk et al. 2019b) was the main focus during the first two decades of formal AF research, but this focus lacked a tractable approach to measuring performance across contexts that has now become a major focus of AF research 'in' development (Coe et al. 2014; Sinclair and Coe 2019). A fresh look at microclimatic effects of trees, adaptive social-ecological systems (and their germplasm exchange in search of locally suitable 
trees, crops, and tree-crop combinations) and the phenological and adaptive responses of trees to temporal variability in water availability and temperature may help us identify relevant concepts and research methods that stem from earlier physiological research that have traction in addressing the current climate emergency.

The passing in November 2019 of one of the founding fathers of tropical AF research, Peter A Huxley (Lundgren et al. 2020), and the availability of his synthesis volume (Huxley 1999a), stimulated us to explore his potential contributions to current scientific questions. At the start of AF research, three lines of research were developed that not only cross-fertilised but also competed for limited research budgets and time allocations.

The first focussed on trees, often 'multipurpose trees', that differed from the timber-oriented tree interest in conventional 'forestry' research. Beyond rapid production of straight poles, trees were identified that helped maintain or improve soil fertility and provided fodder, fruits, resins, medicinal bark, or other products, as well as appropriate levels of shade and complementary rooting habits that ensure compatibility with crops (Sinclair 1996). At least some trees exhibit niche differentiation with crops (Anderson and Sinclair 1993; Cannell et al. 1996; Bayala and Prieto 2019; Bayala et al. 2019a). Large databases were set up to document the hundreds (or thousands) of trees with recorded uses. An ongoing debate on 'prioritisation' addresses the challenge that explicit genetic 'tree improvement' can only deal with a few tree species at the required level of research intensity (Dawson et al. 2011, 2014; Jamnadas et al. 2019), whilst farmers and rural communities may require tree diversity to ensure the productivity and resilience of their livelihoods and landscapes (Vandermeer et al. 1998; Smith-Dumont et al. 2019; van Noordwijk et al. 2019a, 2019b).

The second AF research line looked at the structure-function interactions for any tree in combination with (annual) crops and livestock from the perspective of resource (especially light, water, nutrients) capture, interpreting aboveground and belowground architecture from the perspective of active leaf area and fine-root presence (Luedeling et al. 2016). The third line of research started from a classification (typology) of 'AF systems' based on the trees, crops and livestock components (Nair, 1985; Sinclair 1999), exploring which systems have emerged under what conditions, which ones are expanding and which ones contracting. These three lines of research resulted in correspondingly different emphases of research activity (Table 1). For research lines I and III, it has been a challenge to tease apart climate change as a driver of change from the many other factors (e.g. demography, rural-urban interactions, physical and economic access to markets) that influence farm dynamics. Two types of climate change adaptation have been identified in the literature: firstly, an increase in tree diversity in order to be prepared for increased variability and have options available for adaptive management decisions, and secondly, targeted interventions in order to be prepared for a projected trend in conditions (van Noordwijk et al. 2011a; de Leeuw et al. 2013; Hoang et al. 2014; Catacutan et al. 2017). In funding streams for climate change adaptation, there is a preference for the second type of adaptation, but most farmer surveys have so far provided evidence of the first type (Bayala et al. 2014).

Examples of debates that seek to reconcile different types of evidence and generalisations can be found, for example, in the recent challenge to a basic hypothesis of shade tree-based resilience in coffee and cocoa production systems (Vaast et al. 2016). A recently published study (Abdulai et al. 2018) provided evidence that shaded cocoa in a specific location became more rather than less vulnerable to climate variability, and that previously presumed contributions of AF to resilience of cocoa production are not universal (type II evidence in Table 1). It became clear in the ensuing scientific debate that the research results only applied to a specific fast-growing tree that did not complement the rooting pattern of cocoa and left substantial amounts of subsoil water 


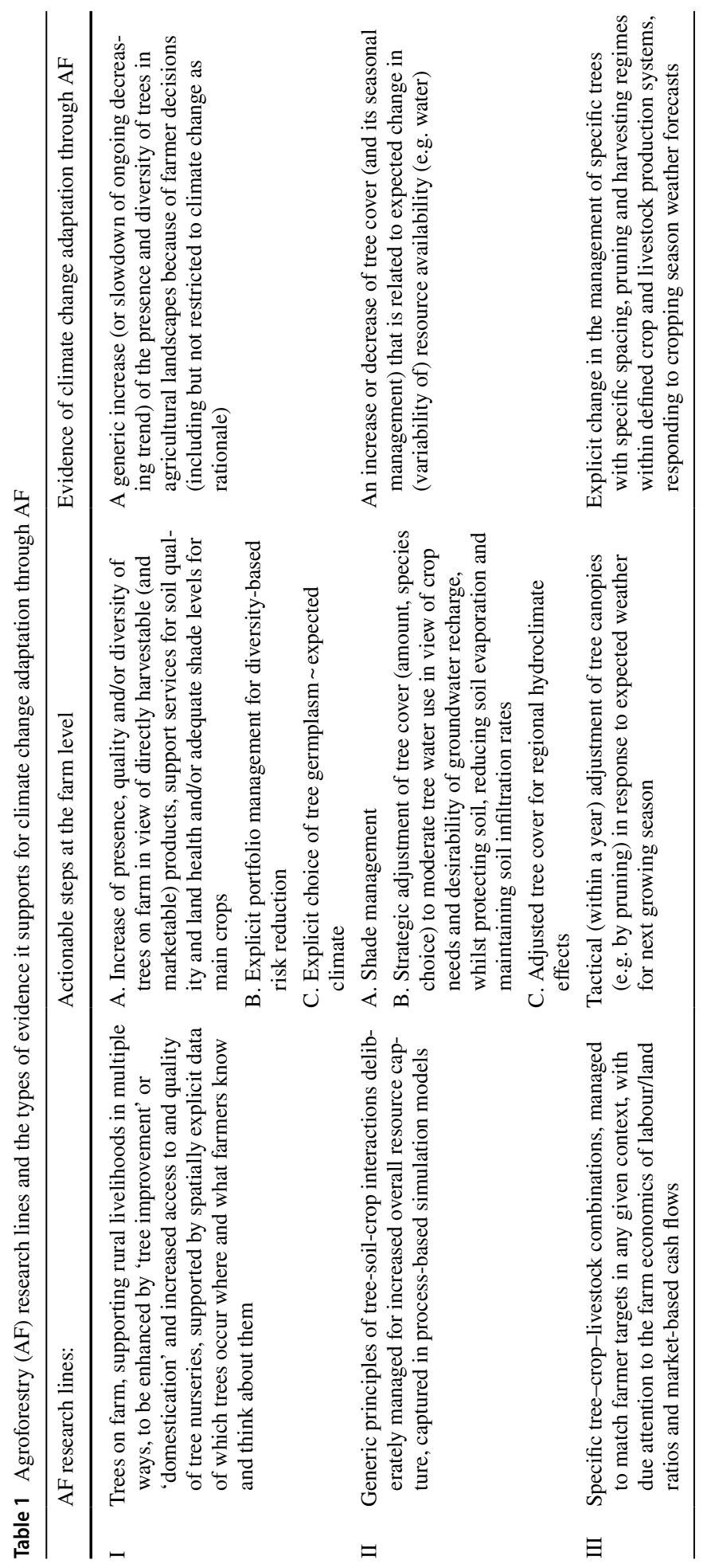


unutilized at the time of drought-induced tree mortality (Norgrove 2018; Wanger et al. 2018). In terms of type II evidence, the initial experiments suggested this had not been the 'right tree for the right place', rather than a generic test of whether shaded cocoa systems can contribute to climate resilience. This echoes many other incidences of where generic claims are made from quite specific experiments. For example, measured effects of a few individual trees of three species (including Senna spectabilis, known to be an aggressive competitor with crops) exacerbating negative impacts of reduced tillage on maize yield in Rwanda and Ethiopia led to claims that combining conservation agriculture with trees was not viable across East Africa (Ndoli et al. 2018) despite its adoption by farmers with a range of other tree species and contexts in the region (Iiyama et al. 2017; Nyaga et al. 2019). Representativeness of case studies is easily overclaimed (Dewi et al. 2017). Further evidence of climate-buffering impacts of trees on coffee, wheat and rice will be discussed below.

Seven interrelated research questions that arise from such considerations (Fig. 1) and are addressed in this review are as follows:

1. How can farmers adapt to global climate change through introducing or better managing trees on farms and in agricultural landscapes?

2. How are site-level impacts of global climate change relevant for tree growth influenced by topography and 'upwind' vegetation?

3. What change in tree phenology, growth and production can be expected for a given variability and/or trend in local climate?

4. How does tree cover, managed on-farm, influence microclimate at the crop level relative to weather station data and the climate models calibrated to such data?

5. How does belowground resource capture by trees and crops (including fodder grasses) interact with modified resource availability under projected climate change regimes?

6. What are the options for farmers to manage AF practices in the context of expected climate change?

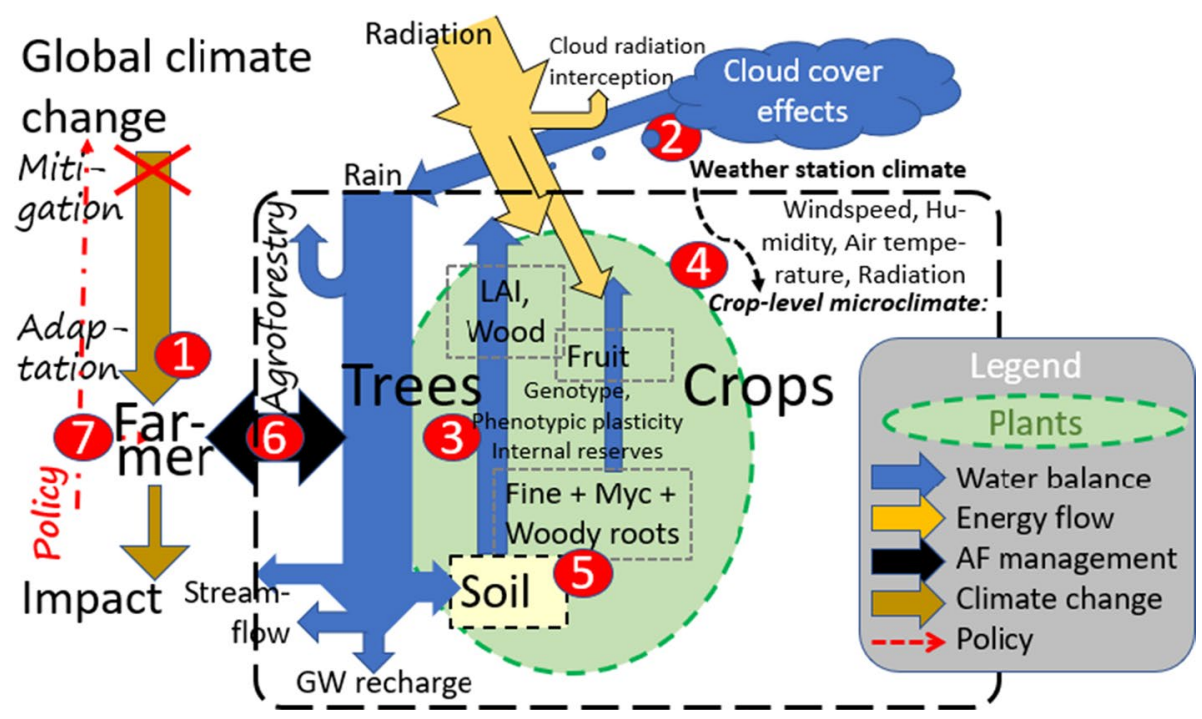

Fig. 1 Schematic representation of the main relationships and 7 research questions discussed in the text 
7. How do social and economic changes associated with the changing climate and response to it affect the adoptability of AF?

We leave question 1 to be addressed together with question 7 at the end of this review. A restriction to the general applicability of ideas and results is that silvo-pastoral systems (Jose and Dollinger 2019; Jose et al. 2019) with trees and livestock, rather than annual crops, as main components and a dominant form of AF in Latin America (Somarriba et al. 2012) offer different challenges and opportunities on the adaptation side but will get little attention here. The focus of our review is on the opportunities for as well as limits to adaptation (van Noordwijk et al. 2011a; Dow et al. 2013) through agroforestry and the research efforts and methods to derive location-specific answers, but we leave the more specific guidance on how to apply this knowledge to other texts referred to.

\section{Method}

We re-read early publications of AF research on agro-climate, tree phenology and treebased microclimate modification, identifying aspects relevant for current discourse, and assessing recent progress or gaps in such progress. We traced citations in the recent literature of publications from the early days of AF research. Teams of authors with a direct connection to early AF research were formed with those with current cutting-edge research experience in climate change adaptation research in and through AF.

\subsection{Agroforestry in the eyes of Peter A Huxley}

In one of his first publications after starting the research effort at the newly established International Council for Research in Agro-Forestry (ICRAF), Peter Huxley (1980) wrote: 'Is there really a place for yet another research discipline? I believe there is, on two main counts. The first, and more pragmatic is that any new amalgam of research ideas needs to be positively encouraged and identified as such, whether it springs from entirely original concepts and practices or not. This is especially so when the component research disciplines, in this case of agriculture and forestry, have established themselves almost as separate entities. The second is that a positive thrust towards the multiple use of land through AF techniques generates a definite need to appraise and re-assemble our research tactics, to consider the increased complexities in space and time which must be dealt with in such systems. We might add, also, that we have to enquire whether our methods of evaluating the outputs of AF systems, in terms of the multiple products and benefits which can accrue, are up to the job.'

'Very few existing agroforestry systems have been studied critically and so far, many still await even broad description. Most agroforestry systems have arisen through the enterprise of indigenous rural communities who have, themselves, evolved them. Whether it is a home garden in Indonesia, a multi-storeyed mixture of trees and agricultural crops in Central America, or a silvo-pastoral system of fodder shrubs and grasses in the Sahel, suggestions for changing the inputs in terms of spatial arrangements, the temporal sequences of crops, or the very plant components themselves are unlikely, in many cases, to be based on measurement data because we have so few to work with.' 
Peter Huxley came to ICRAF with 20 years of research experience in Libya, Uganda and Kenya, with a strong interest in agriculture, climate, tree phenology and coffee, but also ideas about agricultural education and the gap between agriculture and forestry in terms of educational traditions. In his Tropical Agroforestry book (Huxley 1999a), Peter handed over the baton to the next generations of AF researchers with ' ...the first book to provide a comprehensive, analytical account of the principles as well as the practical applications of agroforestry. The focus is on understanding how agroforestry systems function whilst considering the conflicts and compromises that arise because of the farmers' requirements and the biological potentials and restraints of growing woody plants with crops.' 'We should always remember that people are the key elements in agroforestry. Being inclined towards biology I can only refer to some of the socio-economic aspects in this book (and without claiming much authority)'.

\section{Local climate characteristics relevant to tree growth}

\subsection{Huxley's contributions}

Before the rise of global circulation models that account for climates across the globe, local observers of weather patterns that contribute to the long-term mean (30 years by definition) climate had developed a rich language that related wind direction to the type of weather that could be expected, interacting with local topography (e.g. forested mountain slopes, lakes). Huxley and Beadle (1964), for example, analysed short-range variation in weather patterns in Uganda as part of that tradition. It led to a focus on cloudiness as a factor in determining radiation energy, with attention to the diurnal pattern of, for example, morning sunshine and afternoon clouds and rainfall (Huxley 1965). For the humid tropics, seasonal variation in cloud cover may be as important for plant growth as variation in rainfall, especially for deep-rooted trees that can make use of the sunny dry season. The extent of Acacia-Commiphora dry bushland in Africa was found to relate to bimodal versus unimodal rainfall regimes, rather than annual isohyets (White 1983).

Relevant metrics for characterising the climate in which trees are known to occur, and can be expected to thrive elsewhere, were a major issue at the start of AF research (Huxley et al. 1983). There was reason to expect that beyond temperature and mean annual rainfall, other aspects played a role. Early observations of differences in tree distribution by isohyet on sandy and clay soils in Sudan (Jackson 1957; Harrison and Jackson 1958; van Noordwijk 1984) pointed to the importance of local water buffering rather than rainfall as a determinant of tree growth. Given the headquarter location of ICRAF in Kenya, the bimodal rainfall patterns around the equator demanded attention, as both the 'long' and 'short' rainy season were highly variable and, in some years, defying their names. For some trees, the relatively short dry period between these two rainy seasons does not lead to leaf senescence and a new leaf flush; on the other hand, others do respond. The way climates are perceived by trees and crops can thus differ (Huxley 1985b, 1999b). Whilst the location of the Machakos research station in Kenya $\left(1^{\circ} 14^{\prime} \mathrm{S}, 37^{\circ} 27^{\prime} \mathrm{E}\right)$ in the bimodal rainfall zone was initially seen as an advantage (two and contrasting cropping seasons per year yielding interesting data; Huxley and Westley, 1989), the limited 'representativeness' of its climate for the tropics as a whole played a role in abandoning it in the 1990s. Beyond merely the presence/absence of tree species, a more detailed observation of tree phenology in response to seasonal and climatic variation was deemed to be important (Huxley et al. 1989). 


\subsection{Current state of the art}

With the wealth of climate data now available and the 'Big Data' toolbox of analysis, the question of which climate variables have the most skill in accounting for tree distributional patterns can be tackled more directly. For example, Rana et al. (2018) developed MaxEnt models of recorded Alnus species distribution data in Nepal, using a subset of least correlated bioclimatic variables for current conditions (1950-2000), topographic variables and Land Use Land Cover (LULC) data. The major climatic factor that contributes to Alnus nepalensis distribution in Nepal appears to be precipitation during the warmest quarter of the year and precipitation during the driest quarter for Alnus nitida. Neither of these climatic variables has so far been captured in standard AF tree databases. Booth (2018) recently compared phenomenological (correlative) models with mechanistic (physiological) models and suggested that further progress is possible in bringing these strands of knowledge together.

The choice of climate data for determining site suitability for a wide range of tree species can now be left to a final analysis of multiple empirical pathways (Ranjitkar et al. 2016; Lu et al. 2017; Gaisberger et al. 2017; de Sousa et al. 2019). An 'ensemble habitat suitability' can be calculated as the weighted average of suitability estimates predicted by different algorithms (Kindt 2018). Analysis by Noulèkoun et al. (2018) suggested that the climate parameters for predicting tree growth in the year of establishment (longest dry spell in rainy season) differ from those for the subsequent growth of trees with established root systems (overall balance of potential evapotranspiration and rainfall). There is also literature describing the way tree distribution and dynamics respond to rainfall trends over periods of several years and the interactions of these with human activity (Maranz 2009; Mbow et al. 2015; Brandt et al 2016, 2017). Where large-scale tree mortality is noted, anthropogenic disturbances of the water balance and pest and disease outbreaks linked to reduced tree genetic diversity can be hard to distinguish from the effects of extreme events and climate change. Statistical downscaling of climate data to finer resolutions as in the WorldClim data that is widely used in species distribution modelling (http://www.worldclim.org/version1) is reliable for means, but has more uncertainty for the extremes, where the degree of spatial and temporal autocorrelation of events is uncertain.

The relationship between locally generated clouds and rainfall has received considerable attention, as evidence of 'terrestrial recycling' of rainfall, beyond ocean-derived precipitation. Early Global Circulation Models (GCMs) used elevation-temperature relations as they focussed on the global energy balance (modified by atmospheric greenhouse gas concentrations) as a driver of atmospheric pressure differentials and circulation, but ignored many other local features, including a two-way interaction between vegetation and rainfall. Even though the basic data that allow the analysis of terrestrial recycling have been around for nearly two decades (Bosilovich and Schubert 2002) coupled with compelling analysis by van der Ent et al. (2010) that drew attention to the strong geographic patterns in source and sink areas of terrestrial rainfall recycling, it has taken a long time for the upwind-downwind relationship in rainfall and land cover with high rates of evapotranspiration (wetlands, lakes, forests, irrigation schemes) to be noticed (Ellison et al. 2017, 2019; Wang-Erlandson et al. 2018). Important aspects of underlying mechanisms in rainfall triggering by atmospheric particles of biological origin (Morris et al. 2014; van Noordwijk et al. 2015a) and direct influence of forests on air circulation ('biotic pump' Sheil and Murdiyarso 2009) remain frontiers of this science 
(Creed and van Noordwijk 2018). It appears that there is less geographic variation in the mean residence time of atmospheric moisture (around 8 days; van der Ent and Tuinenburg 2017) than in the windspeeds, and thus, the distances travelled before water vapour leads to rainfall (from around $200 \mathrm{~km}$ at windspeeds of $1 \mathrm{~km} / \mathrm{h}$ to $2000 \mathrm{~km}$ at $10 \mathrm{~km} / \mathrm{h}$ or more). Accounting for effects of cloud cover on radiation (Park et al. 2017) can help translate scenarios that differ in fire/haze production and/or forest-based cloud cover to local climate consequences.

\section{Tree phenology response}

\subsection{Huxley's contributions}

Trees are not a taxonomic entity and many plant families contain both trees and non-woody annuals, suggesting that 'woodiness' is an adaptive life-history trait with pros and cons. Huxley (1999a, b) explored the 'woodiness' question in detail. Perenniality postpones the risky phases of seedling establishment and allows plants to make use of 'windows of opportunity' for reproduction that open at long intervals. It also allows for the accumulation of growth resources and gains made in exploring aboveground and belowground space, with leaves and fine roots as ephemeral extensions of the woody architecture that persists. Cannell and Huxley (1969) analysed seasonal differences in the pattern of assimilate movement in branches of Coffea arabica, a study that informed later thinking about plant research and AF (Huxley 1983). The direct observational records of tree flowering, fruiting, leaf flush and leaf senescence in Huxley and van Eck (1974) remained an inspiration for the deeper analysis of tree phenology (Akunda and Huxley 1990), but the resources and patience needed to record the basic data have become hard to assemble.

\subsection{Current state of the art}

The search for genes that make a tree a tree (Groover 2005) has clarified that genes responsible for wood production are also present in plants that do not have the tree habit (Petit and Hampe 2006). Genes involved in the vascular cambium of woody plants are also expressed in the regulation of the shoot apical meristem of Arabidopsis (Groover 2005). This might explain why woodiness can (re)emerge so readily, as observed in many island radiations (for example Böhle et al. 1996).

Predicting changes in tree phenology in response to climate change remains a major challenge for most tree species (Schwartz 1999). There is still often no clarity on what exactly drives transitions between phenological stages. Even greater uncertainty surrounds the sensitivity of tree phenology to changes in these drivers. Reasonable descriptions of tree development during periods of active growth have been achieved with relatively simple thermal time models (Linkosalo et al. 2006), yet it is unclear to what extent such relationships will hold as the climate changes. Whilst this question could be resolved, to some extent, by multi-environment studies, such research is absent for most species (Schwartz 1999).

What remains even more in the dark, but is arguably more critical for adaptation planning, are the mechanisms behind the resumption of active tree growth after a period of inactivity (Campoy et al. 2011). Such phase transitions are observed for most species in locations with pronounced cold or dry seasons (Campoy et al. 2011), and they 
often involve a dormant period during which trees drop all their leaves and suspend active growth. A difference in leaf phenology can impact water use efficiency, gaseous exchange, tree growth and productivity of accompanying crops (Muthuri et al. 2009). In exceptional cases, such phases can even occur during periods that feature climatically favourable conditions, as has been widely reported for Faidherbia albida, a species that thrives in semi-arid environments, even though it loses its leaves during the wet season (Roupsard et al. 1999, 2020). What drives such transitions is often unclear, with variation in photoperiod (Heide, 2008), temperature (Guo et al. 2015), water availability, and insolation (Borchert et al. 2015) reported as influential factors in various situations. The relative importance of all these factors is often ambiguous, and systematic experiments that could overcome this uncertainty are usually lacking. To some extent, and where sizeable datasets exist, statistical methods can elucidate some relationships (Luedeling and Gassner 2012; Ranjitkar et al. 2013), but such studies rarely generate the physiological insights that might allow reliable predictions under conditions that are different from those under which tree behaviour has been observed (Luedeling 2012).

Even for the winter dormancy period of deciduous trees in cold-winter climates, possibly the most extensively modelled phenological phenomenon, our quantitative understanding of the environmental cues and physiological processes involved is insufficient for reliable predictions of climate change impacts (Luedeling 2012). Whilst there is a general agreement on the importance of chilling and forcing temperatures, the role of other drivers, such as humidity, daylength and management, is still under debate (Schwartz 1999). Even though a few models have been developed for predicting dormancy release, the empirical basis of most of these models is slim, prediction successes have been modest, and model development has been stagnant for several decades (Luedeling 2012). Especially when it comes to the critical environmental signal of chill accumulation, existing models are unreliable when used along temperature gradients (Luedeling and Brown 2011; Luedeling et al. 2009), casting doubt on any phenology predictions for future climate scenarios.

What remains elusive in phenology research is a prediction framework that is based on a sound understanding of the physiological processes that underlie tree phenology. There is some hope, however, that such a framework will eventually become possible. For example, recent research has generated increasing clarity on dormancy-related processes, including the genetics of dormancy (Bielenberg et al. 2008), epigenetic regulation (Rios et al. 2014), the role of plant hormones (Liu and Sherif 2019) and oxidative stress (Beauvieux et al. 2018), regulation of intercellular communication (Rinne et al. 2018) and carbohydrate dynamics (Dietze et al. 2014). The current frontier in tree dormancy modelling — and in phenology modelling more generally — is the integration of the knowledge generated over the past few decades into a comprehensive process-based understanding of the drivers of tree phenology and the processes they trigger.

In AF research, a next step is that tree phenology matters for shade impacts on intercropped cereals, with late-flushing trees shading crops after their flowering stage, reducing yield but increasing protein content of the grain (Artru et al. 2017). In a study of phenology of a W. Amazon fruit-bearing shrub, Eugenia stipitate, flowering and fruit production was found to be influenced by the companion trees used in AF when tested in Costa Rica (van Kanten and Beer 2005), whilst the balance between vegetative growth and fruit production in other fruit-bearing shrubs was found to depend on AF context (Delgado et al. 2016). Phenotypic plasticity of roots in mixed tree species AF systems (Kumar and Jose 2018) can alter tree-soil-crop interactions. 


\section{Microclimate modification by trees relevant for crops and livestock}

\subsection{Huxley's contributions}

Before joining ICRAF, Huxley became interested in 'systematic spacing designs' in intercropping research (Huxley and Maingu 1978). Spacing influences both aboveground and belowground distances between plants, and microclimate effects (shade, windspeed, humidity) on water demand for transpiration. It interacts with the volume of soil available per plant for buffering water supply to roots, and the degree of common access and thus competition. As a research approach, Huxley proposed both experiments with tree and crop densities as a primary variable, and direct observation of the microclimatic effects and belowground interactions (Huxley 1985a, b, c, 1987, 1996; Huxley and Mead 1988; Huxley et al. 1989, 1994). Microclimate effects also play a role in the incidence and management of pests and diseases in AF (Huxley and Greenland 1989). In the overview of a physiological approach to tree-crop interactions (Ong and Huxley 1996), the direct coupling of water and energy balances is discussed as the determinant of "production possibility frontiers' in mixed tree-crop systems, with nutrient cycling and erosion control as manageable constraints.

\subsection{Current state of the art}

Microclimate research traditions provide important insights to local ways to deal with global climate change (Stigter 2007, 2016). Shading has been represented in increasingly refined 1D, 2D and 3D models of tree canopies (Quesada et al. 1989; Reid and Ferguson 1992; Charbonnier et al. 2013; Rosskopf et al. 2017). Simple models for light competition in discontinuous tree stands within AF shifted to a 2D representation of space (Talbot and Dupraz (2012). Canopy development was linked to the C (Nygren et al. 1996) and N balance (Nygren and Leblanc 2015), as in the shade and mulch model of alley-cropping systems (van Noordwijk 1996). More comprehensive process-level understanding of tree-soilcrop interactions, informed by various tree-crop interface experiments, has been captured in the 2D Water, Nutrient, Light Capture in Agroforestry Systems (WaNuLCAS) model (Van Noordwijk et al. 2011b), and used, for example, in a bioeconomic exploration of plant density and thinning scenarios for teak (Tectona grandis)-maize systems (Khasanah et al. 2015), water use in trees of different leafing phenological stages in semi-arid Kenya (Muthuri et al. 2004) and exploration of intercropping options for oil palm (Khasanah et al. 2020).

Similar ideas informed a more detailed 3-dimensional tree canopy-crop model (Dupraz et al. 2019) and efforts to make existing crop models responsive to the presence of trees (Luedeling et al. 2016; Smethurst et al. 2017; Burgess et al. 2019). Stand-level light interception models have been modified for horizontally and vertically heterogeneous canopies (Forrester 2014), and used to study latitudinal influence on the light availability for intercrops in an AF alley-cropping system (Dupraz et al. 2018). Detailed microclimatic effects of tree canopies were modelled by Vezy et al. (2018), building on earlier concepts (Wang and Jarvis 1990; Wang et al. 2006). Modelling short-wave radiation distribution in an AF system (Zhao et al. 2003), competition for water (Wanvestraut et al. 2004) and shading response (Zamora et al. 2009) has helped in understanding the cotton/pecan alleycropping systems in the USA. Tree shelterbelt design and management requires predictive 
understanding of wind flow patterns associated with shelterbelt structure, tree height and optical porosity (Zhou et al. 2005; Mize 2008).

Aboveground microclimate interacts with the soil water balance, with tree effects including hydraulic equilibration. Bayala et al. (2015) reviewed advances in knowledge of processes in soil-tree-crop interactions in parkland systems in the West African Sahel, focussing on coupled energy and water balance and two-way hydraulic redistribution (Bayala et al. 2008) as a mechanism by which moisture in deeper soil layers, accessed only by tree roots, becomes available to crop roots. The degree to which such processes contribute to the agronomically proven positive effects on millet and cowpea in Ziziphus-based cropping systems remains to be explored (Bado et al. 2020). Hydraulic equilibration in intercropping deeper and shallower rooted plants (Kizito et al. 2012; Izumi et al. 2018) has been portrayed as 'bio-irrigation' (Bogie et al. 2018). It depends, however, on conditions where deeper soil water reserves are replenished during episodes with temporary rainfall excess over evapotranspiration (van Noordwijk and Ong, 1999; van Noordwijk et al. 2014).

Panwar et al. (2020) investigated the diurnal response of surface and air temperatures to evaporative conditions for different vegetation types and found that surface temperature, in contrast to air temperature, reflected evaporative cooling in short-stature vegetation. In forests, however, aerodynamic conductance dominated over evaporative cooling, and surface temperature was not a good predictor of current evapotranspiration.

Shade trees in coffee and cocoa have been analysed for the disadvantages and desirable characteristics of a range of shade trees (Beer 1987; 1988; 1991), and translated to farmerlevel management options (Beer et al. 1997). Specific AF practices that may improve agricultural performance responding to climate change include shade trees buffering rising temperatures to stabilise the yield of crops like coffee (Rahn et al. 2014, 2018), and increasing the yield of food staples through lowering daytime temperatures and reducing heat stress (Sida et al. 2018; Wangpakapattanawong et al. 2017). Agroecological research beyond AF has demonstrated the relevance of diversity, increasing the resilience of crops to climate-induced pest and disease pressures (Harrison et al. 2019) or increased soil carbon and mulch associated with increased water infiltration and holding capacity and reduced soil evaporation (Ilstedt et al. 2016; Bayala et al. 2019b), improving the resilience of crops to drought (Minasny and McBratney, 2018). A recent meta-analysis of studies carried out in sub-Saharan Africa showed that on average, AF systems in sub-Saharan Africa increase crop yield whilst maintaining delivery of regulating/maintenance ecosystem services (Kuyah et al 2019).

\section{Belowground interactions}

\subsection{Huxley's contributions}

Before joining ICRAF, Huxley had gained experience with direct observation (Huxley and Turk, 1975) and ${ }^{32} \mathrm{P}$ tracer studies of coffee (Huxley et al. 1974). He was keen to bring a 'whole-plant physiology' approach to the study of aboveground and belowground trees and the way woody architecture defines the bounds of opportunistic resource capture (Huxley 1994, 1999a). Root system research was constrained not only by the spatial variability of the soil as substrate and the adaptive responses of plant root systems to such heterogeneity but also by the challenges of graphical representation (Rao et al. 1993). Woody root architecture proved to be a direct basis not only for understanding belowground competition for 
water resources (Ong and Huxley 1996) but also for clarifying complementarity, as water can flow in both directions: towards the shoot and from wetter to drier layers of soil.

\subsection{Current state of the art}

Bayala and Prieto (2019) reviewed water acquisition, sharing and redistribution by roots in AF systems. Van Noordwijk et al. (2015b) summarised the current understanding of the way woody root system architecture relates to tree physiology via adjustments in shoot/root ratio (van Noordwijk and de Willigen 1987) and local response to soil heterogeneity. Fractal branching rules apply for woody parts aboveground and belowground, but their parameters may be unrelated (Van Noordwijk and Mulia 2002). Aboveground allometry differs for solitary trees from those growing in closed stands, but tree shape plasticity is species-dependent (Harja et al. 2012). A recent fractal branching study on the shea tree (Vitellaria paradoxa) in Mali analysed differences in tree architecture between climate zones, with consequences for allometric relations (Sanogo et al. 2021). Mulia et al. (2010) reconciled a generic fractal branching pattern with such opportunistic response, operating at different time scales. Van Noordwijk et al. (1998) reviewed the understanding of plant roots in relation to global climate change, exploring the internal resource economy of maintaining fine-root biomass versus the carbon costs of new root expansion when favourable conditions for nutrient and water uptake return. Empirical research showed very different root system responses amongst tree species to soil drying and shoot pruning (Jones et al. 1998), incorporating the avoidance of hydraulic redistribution by cutting off the fine roots that might leak night-time water into zones that are not functional for the tree. There is little direct physiological evidence yet on how genotypic variation deals with such trade-offs. The few available estimates of fine-root turnover (van Noordwijk et al. 2004) match the theory so far, but progress in compiling relevant datasets has been slow. Kuyper et al. (2004) reviewed mycorrhiza management in AF, but there is still a need to clarify the role of common mycorrhizal networks in hydraulic redistribution mechanisms as an ecological mechanism to buffer against droughts and ensure productivity in regions with increasing variability in rainfall (Bayala and Prieto 2019).

Many tree-soil-crop interactions in AF have focused on $\mathrm{N}$ availability (Haggar and Beer 1993; Haggar et al. 1993; Rowe et al. 1998) and N retention (Harmand et al. 2007). Studies of nutrient cycling in traditional AF systems (Glover and Beer 1986; Kass and Somarriba 1999) and intensively managed AF systems of cacao and timber species (Imbach et al. 1989; Somarriba and Beer 2011; Somarriba et al. 2014) helped to understand generic patterns and their site-specific manifestation.

Recent advances and perspectives on belowground functioning of AF systems (Cardinael et al. 2020) include, beyond the water and nitrogen cycle, advances on functional trait classifications of roots (Isaac and Borden 2020; Borden et al. 2020) and an understanding of how competition with winter crops induces deeper rooting of walnut trees in a Mediterranean alley-cropping AF system (Cardinael et al. 2015a, b). Further progress on tree root system is in recognition of the soil binding and soil anchoring functions that together reduce landslide risks on sloping land, subject to high-intensity rainfall events (Hairiah et al. 2020a, b).

Spatial patterns of variability of fine roots in coffee AF (Mora and Beer 2013) and fine-root dynamics of coffee in association with two shade trees (van Kanten et al. 2005) have helped to better understand niche differentiation. Spatially explicit impacts on 
distribution of soil organic carbon in alley cropping combine aboveground and belowground inputs (Cardinael et al. 2015a, b). Where earlier reviews of ecological processes in tropical and temperate AF systems paid equal attention to belowground and aboveground processes (Batish et al.2007), subsequent research emphasised the close linkage between these two categories in linking nutrient and carbon cycles (Payan-Zelaya et al. 2013; Udawatta et al. (2017).

Recent reviews established that AF boosts soil health in the humid and sub-humid tropics (Muchane et al. 2020) and that it influences soil fauna and their functions (Marsden et al. 2020). Beyond general conclusions on AF and ecosystem services (Jose 2009), greater mechanistic precision becomes feasible and can help in assessing risks and potential responses to global climate change. For example, increased rates of litter decomposition increase risks of bare soil conditions during part of the year. Yet, the effects of global warming on litter decay rates appear to be mixed as temperature effects interact with moisture and litter quality (Kumar 2008). Annual litterfall rates in plantations and AF systems (2-10 $\mathrm{mg} \mathrm{ha}^{-1} \mathrm{y}^{-1}$ ) are $50-100 \%$ of peak foliar biomass (Kumar 2008), with woody fractions around $15 \%$ of the total.

Belowground interactions that affect $\mathrm{C}$ storage in soils have been a major research interest in the past decades. Contrary to expectations of proportionality of aboveground biomass and soil $\mathrm{C}$ storage, a recent meta-review found that experimental effects of elevated $\mathrm{CO}_{2}$ concentrations on soil carbon storage are inversely proportional to their effects on aboveground biomass (Terrer et al. 2021). Positive effects on soil $\mathrm{C}$ were found in nutrientlimited situations with small aboveground biomass responses. Neutral (or even negative) soil $\mathrm{C}$ changes where aboveground biomass response was strong, as was common where trees were involved in the experiments. These findings are aligned with early predictions for elevated $\mathrm{CO}_{2}$ effects from a 'functional equilibrium' perspective on the root:shoot relations in plants in nutrient-limited situations but not where water is limiting as increased $\mathrm{CO}_{2}$ concentrations will modify the stomata level exchange between $\mathrm{H}_{2} \mathrm{O}$ vapour loss and $\mathrm{CO}_{2}$ uptake (van Noordwijk et al. 1998). In the relationship between modified root biomass and soil $\mathrm{C}$ storage, root (and mycorrhizal hyphae) turnover will increase soil C inputs. However, root-mediated mineralisation (for example by phosphatase release) may work in the opposite direction. Whilst most of the literature on $\mathrm{AF}$ and $\mathrm{C}$ sequestration stays at the level of tree planting (Kumar and Nair 2011; Anderson and Zerriffi 2012; Jose and Bardhan 2012; Chapman et al. 2020) or measured soil C stocks (Shi et al. 2018; Chatterjee et al. 2018; Corbeels et al. 2019), some studies have delved deeper into the processes of root-aggregate interactions (Albrecht and Kandji 2003) and simultaneous effects on soil macroporosity (bulk density) and $C_{\text {org }}$ concentrations (Hairiah et al. 2020a, b; Saputra et al. 2020). Other studies have addressed the lack of visibility of trees in agricultural lands in current $\mathrm{C}$ accounting systems at the national scale (Rosenstock et al. 2019a, b, c), as precondition for economic incentives to reach the farmgate.

\section{Agroforestry experiments: beyond observational studies}

\subsection{Huxley's contributions}

Huxley has left an important legacy of research methods as well as results, through the methods he used, that he wrote about and that he encouraged others to develop and describe. His approach was one of balancing careful attention to theory whilst being 
practical and opportunistic (Huxley 1985b). He emphasised the specific challenges of research in AF, saying '...we cannot simply borrow analogous examples of research methodology from agriculture or forestry as they stand in order to reach a solution, but there are specific reasons why we have to adapt, develop and improvise new modifications' (Huxley 1985c). Much of Huxley's own research was at the plant level, but he saw it embedded in a process of understanding farming systems and interacting with farmers. These elements were brought together in Huxley and Mead (1988) that proposed both the flexible approach to on-farm experimentation and observational studies based on the careful measurement around existing individual trees, both of which are now widely used. He was intrigued by novel experimental layouts (Huxley et al 1994; Huxley 1985a). This included promoting the use of systematic designs in AF research and agronomy, a trend that has not continued in $\mathrm{AF}$ as results often proved inconclusive. His work with Roger Mead led to the development of an entirely novel class of experimental design they labelled HAHA (hedge alley hedge alley) that turned out to be interesting for design theory, but again maybe not useful given the way AF research developed (ICRAF 1988, Nester 1994). Huxley was ahead of his time in recognising the need for careful data management of highly structured datasets and supported the development of early software tools for doing that (Roger and Muraya 1991). Likewise, he was ahead of trends in using visual methods to detect and display patterns in data when these had to be drawn by hand (Huxley 1965; Huxley and Van Eck 1974; Huxley et al 1994).

\subsection{Current state of the art}

Many case studies provide evidence (type I in Table 1) on the relevance of AF for climate change-resilient agriculture (Nguyen et al. 2013; Coulibaly et al. 2014; Simelton et al. 2015; Gram et al. 2018; Castro et al. 2018; Quandt et al. 2019). Progress on types II and III evidence described in Table 1 is patchier yet. The systematic designs promoted by Huxley are only rarely used, as the interpretation of results is not straightforward, given confounding effects aboveground and belowground. Another layer of complexity is the landscape scale both for the observational and systematic designs that will require a combination of field-level yield mapping, remote sensing and modelling for long-term data collection/ assessment to investigate how resilient to climate change AF systems are and to what extent they mitigate it (Bayala et al. 2015).

With the increased interest in temperate-zone $\mathrm{AF}$, farm economic considerations are as important as biophysical ones (Wojtkowski 1998; Jose and Gordon 2007; Jose et al. 2012; Pantera et al. 2018), but there is also interest in the ways trees can help return some of the functionality lost when agricultural mechanisation and intensification homogenised the landscape (Mosquera-Losada et al. 2012; Den Herder 2017; Kay et al. 2019). Design of long-term AF field trials (Lovell et al. 2018) will often have to shy away from fully factorial designs feasible in crop monocultures and follow a farming system approach, in which a few differently managed systems are compared to controls. Instead of standard statistical approaches, biophysical modelling is used to test the fit of predicted versus measured outputs of the systems to analyse the functioning of the mixtures. Parameter-sparse AF models (Keesman et al. 2011) can zoom in on farm management decisions but will not allow exploration of conditions beyond the conditions for which models were parameterized.

On the other end of the research spectrum, the ecological toolbox of analysing diverse and spatially complex systems (Somarriba et al. 2001; De Souza et al. 2012; Deheuvels 
et al. 2012; Cassano et al. 2014) needs to be coupled to the social methods to appreciate diversity in expectations, goals and management practices (Jerneck and Olsson, 2013, Jerneck and Olsson 2014; Sari et al. 2020; Mulyoutami et al. 2020).

Whilst in principle, trade-offs between crop intensification and ecosystem services exist in most forms of AF (Vaast et al. 2005; DeClerk et al. 2012; Vaast and Somarriba 2014), many systems operate so far below yield potential that considerable win-win opportunities exist, reducing risks whilst increasing performance under normal circumstances (De Beenhouwer et al. 2013; Schroth et al. 2016; Gomes et al. 2020).

\section{Discussion}

In the line of Huxley, research combining the best of process-level understanding with AF designs with a proven track record (Ong et al. 2015) may have been the most successful yet in the dry tropics (Bayala et al. 2015). Combining direct canopy interception and transpiration data of trees with effects on water infiltration, influenced by trees, Ilstedt et al. (2016) derived an estimate of an optimal intermediate tree density for such parklands, from a perspective of groundwater recharge. Further analysis of how such optimum depends on climate variability and climate change is in progress.

Much of the analysis of AF systems responding to climate change has been on the level of 'dealing with the consequences' of ongoing climate change and contributing to mitigation at the greenhouse gas emission driver level (Syampungani et al. 2010; Duguma et al. 2014; Mbow et al. 2014a). In terms of the AF research lines and the actionable consequences at the farm level (Table 1), progress is largely confined to line I, especially category IA. Publications from all tropical continents report farmers knowledge on the relevance of tree cover for climate buffering and preferences for specific trees in the local context (Nyong et al. 2007, Chaudhury et al. 2011; Pramova et al. 2012; Thorlakson and Neufeldt 2012; Charles et al. 2013; de Zoysa and Inoue 2014; Lasco et al. 2014a, 2014b, Pandey et al. 2015; Lasco et al. 2016; Newaj et al. 2016). This matches the recorded global increase in tree cover on farmed lands, but with regional differences (Zomer et al. 2016; van Noordwijk et al. 2019b). Explicit attention to tree diversity management on a farm (line IB) in this context is scarce yet (van Noordwijk et al. 2019b; Rosenstock et al. 2019a). Explicit adjustment of species choice to expected climate (Line IC) was discussed, for example, in Luedeling et al. (2014), Booth (2018) and de Sousa et al. (2019). Studies of tree-level response to long-term interannual climate variability are scarce yet (Mokria et al. 2017). There still also is a challenge of novel future climatic conditions without presentday climate analogue (Luedeling et al. 2014), whilst increased atmospheric $\mathrm{CO}_{2}$ concentrations change the stomatal water use efficiency and can change the hydroclimatic requirements for tree growth.

Research line II, explicit adjustment of quantity and quality of tree cover to match expected and ongoing climate change, is still relatively scarce. The most discussed is the adjustment of shade levels in tree crops such as coffee and cocoa (Tscharntke et al. 2011). Trees are commonly selected to survive in and reduce urban heat islands (Lanza and Stone 2016; Pretzsch et al. 2017), but not yet explicitly to serve as air coolers in cropped fields that otherwise may be too hot (Ellison et al. 2017). Attention to such applications is, however, emerging (Roy et al. 2011; Tewari et al. 2014). Most of the examples in this category deal with the interface of energy and water balance. Specific attention to the relatively high 
intensity of land-use change in 'water towers' is needed (Dewi et al. 2017). The trade-offs between downstream and downwind water availability depend on coherent metrics, as discussed by van Noordwijk et al. (2016, 2019c).

We are not aware yet of applications in research line III, partly as season-level weather forecasts are not yet reliable. A recent finding that may make El Niño events predictable a year in advance (Meng et al. 2020) may open new avenues for such applications. At scales above the farm level, however, there are impacts on cloud cover, biological rainfall generation (BRG, as the counterpart of biological nitrogen fixation (BNF), van Noordwijk et al. 2015a), and meso-climate/microclimate that can be influenced by land cover, and thus potentially be managed. Ambitious, quantitative schemes that relate farmer-level choice and options to interventions at landscape and regional scale that may influence rainfall patterns and interact with global circulation models include many relations that deserve further analysis and targeted data collection.

Such analysis may show that the policy agenda for climate change resilience can be more encompassing than is currently realised. At the start of an explicit interest in sustainability research 30 years ago, Huxley $(1989,1995)$ contributed ideas that seek systemlevel relevance for mechanisms and relations understood at the component level. Such an approach, as challenging as it is, can still help in fully accounting for the various ways in which tree cover at regional and landscapescales can modify the climate, interacting with global circulation and greenhouse gas effects. Ultimately, policy interest is not in achieving climate change adaptation as such (with or without the use of AF), but in progress across the totality of the Sustainable Development Goals of Agenda 2030. Prospects for growing recognition of a rural development pathway that takes agroecology and AF seriously are increasing (Mbow et al. 2014b; van Noordwijk et al. 2018, 2019d), with special attention to areas of high vulnerability such as small islands (van Noordwijk 2019c). To contribute to such progress, however, AF research methods will have to keep evolving, building on 40 years of progress (van Noordwijk and Coe 2019).

\section{Conclusions}

1. Agroforestry can contribute to climate change adaptation in four ways: (1) Reversal of negative trends in diverse tree cover as generic portfolio risk management strategy; (2) targeted, strategic, shift in resource capture (e.g. light, water) to adjust to changing conditions (e.g. lower or more variable rainfall, higher temperatures); (3) vegetation-based influences on rainfall patterns; and/or (4) adaptive, tactical, management of tree-crop interactions based on weather forecasts for the (next) growing season. Evidence for the generic risk reduction by increase of buffer functions and diversity is strong; examples of specific adaptations to confirmed trends in local climate are still sparse, but start to emerge, especially with respect to hydroclimatic change.

2. Quantification of microclimate within and around tree canopies showed a gap between standard climate station data (designed to avoid tree influences) and the actual climate in which crop and tree meristems or livestock operate in real-world AF. Where global scenario modelling of 'macroclimate' change in mean annual rainfall and temperature extrapolates from climate station conditions in past decades, it ignores microclimate effects of trees. 
3. There still is a shortage of long-term phenology records to analyse tree biological responses across a wide range of species to climate variability, especially where flowering and pollination matter, linked to the way the plant perceives temperature and drought signals, and impacts on pollinator presence at the required time and place.

4. Physiological understanding of aboveground and belowground resource capture can complement farmer knowledge and help guide policy decisions that allow AF solutions to emerge and the choice of tree germplasm to be adjusted for the growing conditions expected over the lifetime of a tree.

5. The emerging recognition for agroforestry as part of national climate change adaptation strategies is encouraging but requires backup by quantitative risk analyses.

Acknowledgements The authors acknowledge the direct (or indirect for the younger amongst us) inspiration by Peter A Huxley to apply rigorous scientific analysis to agroforestry questions. We appreciate discussions with the late Chin K. Ong in developing this contribution.

Open Access This article is licensed under a Creative Commons Attribution 4.0 International License, which permits use, sharing, adaptation, distribution and reproduction in any medium or format, as long as you give appropriate credit to the original author(s) and the source, provide a link to the Creative Commons licence, and indicate if changes were made. The images or other third party material in this article are included in the article's Creative Commons licence, unless indicated otherwise in a credit line to the material. If material is not included in the article's Creative Commons licence and your intended use is not permitted by statutory regulation or exceeds the permitted use, you will need to obtain permission directly from the copyright holder. To view a copy of this licence, visit http://creativecommons.org/licenses/by/4.0/.

\section{References}

Abdulai I, Vaast P, Hoffmann MP, Asare R, Jassogne L, Van Asten P, Rötter RP, Graefe S (2018) Cocoa agroforestry is less resilient to sub-optimal and extreme climate than cocoa in full sun. Glob Change Biol 24(1):273-286

Akunda E, Huxley PA (1990) The application of phenology to agroforestry research. ICRAF Working Paper No 63. ICRAF, Nairobi, $50 \mathrm{pp}$.

Albrecht A, Kandji ST (2003) Carbon sequestration in tropical agroforestry systems. Agric Ecosyst Environ 99:15-27. https://doi.org/10.1016/S0167-8809(03)00138-5

Altieri MA, Nicholls CI (2017) The adaptation and mitigation potential of traditional agriculture in a changing climate. Clim Change 140(1):33-45

Anderson EK, Zerriffi H (2012) Seeing the trees for the carbon: agroforestry for development and carbon mitigation. Clim Change 115:741-757. https://doi.org/10.1007/s10584-012-0456-y

Anderson LS, Sinclair FL (1993) Ecological interactions in agroforestry systems. Agroforest Abstr 6(2):5791 and Forest Abstr 54(6):489-523

Artru S, Garré S, Dupraz C, Hiel MP, Blitz-Frayret C, Lassois L (2017) Impact of spatio-temporal shade dynamics on wheat growth and yield, perspectives for temperate agroforestry. Eur J Agron 82:60-70

Bado BV, Whitbread A, Laminou M, Manzo S (2020) Improving agricultural productivity using agroforestry systems: performance of millet, cowpea, and Ziziphus-based cropping systems in West Africa Sahel. Agric Ecosyst Environ 295, https://doi.org/10.1016/j.agee.2020.107175

Batish DR, Kohli RK, Jose S, Singh HP (eds) (2007) Ecological basis of agroforestry. CRC Press, Boca Raton, Fl (USA)

Bayala J, Prieto I (2019) Water acquisition, sharing and redistribution by roots: applications to agroforestry systems. Plant Soil. https://doi.org/10.1007/s11104-019-04173-z

Bayala J, Heng LK, van Noordwijk M, Ouedraogo SJ (2008) Hydraulic redistribution study in two native tree species of agroforestry parklands of West African dry savanna. Acta Oecol 34(3):370-378

Bayala J, Sanou J, Teklehaimanot Z, Kalinganire A, Ouédraogo SJ (2014) Parklands for buffering climate risk and sustaining agricultural production in the Sahel of West Africa. Curr Opin Env Sust 6:28-34 
Bayala J, Sanou J, Teklehaimanot Z, Ouedraogo SJ, Kalinganire A, Coe R, van Noordwijk M (2015) Advances in knowledge of processes in soil-tree-crop interactions in parkland systems in the West African Sahel: a review. Agric Ecosyst Environ 205:25-35

Bayala J, Öborn I, Dupraz C (2019a) Belowground resource sharing in mixed tree-crop systems: methods to better understand belowground interactions. In: van Noordwijk M (ed) Sustainable development through trees on farms: agroforestry in its fifth decade. World Agroforestry (ICRAF), Bogor, pp 93-109.

Bayala J, Sanou J, Bazié HR, Coe R, Kalinganire A, Sinclair FL (2019b) Regenerated trees in farmers' fields increase soil carbon across the Sahel. Agrofor Syst.https://doi.org/10.1007/s10457-019-00403-6

Beauvieux R, Wenden B, Dirlewanger E (2018) Bud dormancy in perennial fruit tree species: a pivotal role for oxidative cues. Front Plant Sci. https://doi.org/10.3389/fpls.2018.00657/full

Beer J (1987) Advantages, disadvantages and desirable characteristics of shade trees for coffee, cacao and tea. Agrofor syst 5(1):3-13

Beer J (1988) Litter production and nutrient cycling in coffee (Coffea arabica) or cacao (Theobroma cacao) plantations with shade trees. Agrofor Syst 7(2):103-114

Beer J (1991) Implementing on-farm agroforestry research: lessons learned in Talamanca. Costa Rica Agrofor syst 15(2-3):229-243

Beer J, Fassbender HW, Heuveldop J (eds.) (1987) Advances in agroforestry research. Proceedings of a seminar Sept 1-11, 1985. CATIE, Turrialba (Costa Rica), http://bibliotecadigital.infor.cl/handle/20. $500.12220 / 1645$

Beer J, Muschler R, Kass D, Somarriba E (1997) Shade management in coffee and cacao plantations. Agrofor syst 38(1-3):139-164

Bielenberg DG, Wang Y, Li Z, Zhebentyayeva T, Fan S, Reighard GL, Scorza R, Abbott AG (2008) Sequencing and annotation of the evergrowing locus in peach [Prunus persica (L) Batsch] reveals a cluster of six MADS-box transcription factors as candidate genes for regulation of terminal bud formation. Tree Genet Genomes 4:495-507

Bogie NA, Bayala R, Diedhiou I, Conklin MH, Fogel ML, Dick RP, Ghezzehei TA (2018) Hydraulic redistribution by native sahelian shrubs: bioirrigation to resist in-season drought. Front Environ Sci 6:98

Böhle UR, Hilger HH, Martin WF (1996) Island colonization and evolution of the insular woody habit in Echium L (Boraginaceae). Proc Nat Acad Sci 93(21):11740-11745

Booth TH (2018) Species distribution modelling tools and databases to assist managing forests under climate change. For Ecol Man 430:196-203

Borchert R, Calle Z, Strahler AH, Baertschi A, Magill RE, Broadhead JS, Kamau J, Njoroge J, Muthuri CW (2015) Insolation and photoperiodic control of tree development near the equator. New Phytol 205:7-13

Borden KA, Anglaaere LCN, Owusu S, Martin AR, Buchanan SW, Addo-danso SD, Isaac ME (2020) Soil texture moderates root functional traits in agroforestry systems across a climatic gradient. Agric Ecosyst Environ 295:106915. https://doi.org/10.1016/j.agee.2020.106915

Bos SPM, Pagella T, Kindt R, Russell AJM, Luedeling E (2015) Climate analogs for agricultural impact projection and adaptation-reliability test. Front Environ Sci. https://doi.org/10.3389/fenvs20150 0065

Bosilovich MG, Schubert SD (2002) Water vapor tracers as diagnostics of the regional hydrologic cycle. J Hydrometeorology 3(2):149-165

Brandt M, Hiernaux P, Tagesson T, Verger A, Rasmussen K, Diouf AA, Mbow C, Mougin E, Fensholt R (2016) Woody plant cover estimation in drylands from Earth Observation based seasonal metrics. Remote Sens Environ 172:28-38

Brandt M, Rasmussen K, Peñuelas J, Tian F, Schurgers G, Verger A, Mertz O, Palmer JR, Fensholt R (2017) Human population growth offsets climate-driven increase in woody vegetation in sub-Saharan Africa. Nat Ecol Evol 1(4):p0081

Burgess PJ, Graves AR, García de Jalón S, Palma JHN, Dupraz C, van Noordwijk M (2019) Modelling agroforestry systems. Pp 209-238 In: Mosquera-Losada MR, Prabhu R (Eds) Agroforestry for Sustainable Agriculture. Burleigh Dodds.

Burke MB, Lobell DB, Guarino L (2009) Shifts in African crop climates by 2050, and the implications for crop improvement and genetic resources conservation. Glob Environ Chang 19(3):317-325

Campoy JA, Ruiz D, Egea J (2011) Dormancy in temperate fruit trees in a global warming context: a review. Sci Hortic 130:357-372

Cannell MGR, Huxley PA (1969) Seasonal differences in the pattern of assimilate movement in branches of Coffea arabica. Ann App Biol 64(2):345-357

Cannell MGR, van Noordwijk M, Ong CK (1996) The central agroforestry hypothesis: the trees must acquire resources that the crop would not otherwise acquire. Agrofor Syst 34(1):27-31 
Cardinael R, Chevallier T, Barthès BG, Saby NP, Parent T, Dupraz C, Bernoux M, Chenu C (2015) Impact of alley cropping agroforestry on stocks, forms and spatial distribution of soil organic carbon-a case study in a Mediterranean context. Geoderma 259:288-299

Cardinael R, Mao Z, Prieto I, Stokes A, Dupraz C, Kim JH, Jourdan C (2015) Competition with winter crops induces deeper rooting of walnut trees in a Mediterranean alley cropping agroforestry system. Plant Soil 391:219-235. https://doi.org/10.1007/s11104-015-2422-8

Cardinael R, Umulisa V, Toudert A, Olivier A, Bockel L, Bernoux M (2018) Revisiting IPCC Tier 1 coefficients for soil organic and biomass carbon storage in agroforestry systems. Environ Res Lett 13:1-20. https://doi.org/10.1088/1748-9326/aaeb5f

Cardinael R, Mao Z, Chenu C, Hinsinger P (2020) Belowground functioning of agroforestry systems: recent advances and perspectives. Plant Soil 453:1-13. https://doi.org/10.1007/s11104-020-04633-X

Carter S, Arts B, Giller KE, Soto Golcher C, Kok K, de Koning J, van Noordwijk M, Reidsma P, Rufino MC, Salvini G, Verchot L, Wollenberg E, Herold M (2018) Climate-smart land use requires local solutions, transdisciplinary research, policy coherence, and transparency. Carbon Management 9(3):291-301

Cassano CR, Barlow J, Pardini R (2014) Forest loss or management intensification? Identifying causes of mammal decline in cacao agroforests. Biol Cons 169:14-22

Castro P, Azul AM, Leal Filho W, Azeiteiro UM (eds) (2018) Climate change-resilient agriculture and agroforestry: ecosystem. Springer, Berlin

Catacutan DC, Van Noordwijk M, Nguyen TH, Öborn I, Mercado AR (2017) Agroforestry: contribution to food security and climate-change adaptation and mitigation in Southeast Asia. White Paper, World Agroforestry Centre (ICRAF) Southeast Asia Regional Program, Bogor

Chapman M, Walker WS, Peter SCC, Farina M, Griscom BW, Baccini A (2020) Large climate mitigation potential from adding trees to agricultural lands. Glob Chang Biol 26(4357-4365):1-9. https://doi.org/10.1111/gcb.15121

Charbonnier F, Le Maire G, Dreyer E, Casanoves F, Christina M, Dauzat J, Eitel JU, Vaast P, Vierling LA, Roupsard O (2013) Competition for light in heterogeneous canopies: application of MAESTRA to a coffee (Coffea arabica L.) agroforestry system. Agric For Meteorol 181:152-169

Charles RL, Munishi PKT, Nzunda EF (2013) Agroforestry as adaptation strategy under climate change in Mwanga District, Kilimanjaro. Tanzania Int J Environmental Protection 3(11):29-38

Chatterjee N, Nair PKR, Chakraborty S, Nair VD (2018) Changes in soil carbon stocks across the Forest-Agroforest-Agriculture/Pasture continuum in various agroecological regions: a meta-analysis. Agric Ecosyst Environ 266:55-67. https://doi.org/10.1016/j.agee.2018.07.014

Chaudhury M, Ajayi OC, Hellin J, Neufeldt H (2011) Climate change adaptation and social protection in agroforestry systems: enhancing adaptive capacity and minimizing risk of drought in Zambia and Honduras. ICRAF Working Paper No 137. World Agroforestry Centre, Nairobi. 105716/ WP11269PDF

Coe R, Sinclair F, Barrios E (2014) Scaling up agroforestry requires research 'in' rather than 'for' development. Curr Opin Env Sust 6:73-77

Corbeels M, Cardinael R, Naudin K, Guibert H, Torquebiau E (2019) The 4 per 1000 goal and soil carbon storage under agroforestry and conservation agriculture systems in sub-Saharan Africa. Soil Tillage Res 188:16-26. https://doi.org/10.1016/j.still.2018.02.015

Coulibaly YN, Mulia R, Sanou J, Zombré G, Bayala J, Kalinganire A, van Noordwijk M (2014) Crop production under different rainfall and management conditions in agroforestry parkland systems in Burkina Faso: observations and simulation with WaNuLCAS model. Agroforest Syst 88(1):13-28

Creed IF, van Noordwijk M (2018) Forest and water on a changing planet: vulnerability, adaptation and governance opportunities a global assessment report. World Series Volume 38. IUFRO, Vienna.

Dawson IK, Vinceti B, Weber JC, Neufeldt H, Russell J, Lengkeek AG, Kalinganire A, Kindt R, Lillesø JPB, Roshetko J, Jamnadass R (2011) Climate change and tree genetic resource management: maintaining and enhancing the productivity and value of smallholder tropical agroforestry landscapes: a review. Agrofor Syst 81(1):67-78

Dawson IK, Carsan S, Franzel S, Kindt R, van Breugel P, Graudal L, Lilles $\emptyset$ JPB, Orwa C, Jamnadass R (2014) Agroforestry, livestock, fodder production and climate change adaptation and mitigation in East Africa: issues and options. World Agroforestry Center, Nairobi

De Beenhouwer M, Aerts R, Honnay O (2013) A global meta-analysis of the biodiversity and ecosystem service benefits of coffee and cacao agroforestry. Agric Ecosyst Environ 175:1-7. https://doi.org/ 10.1016/j.agee.2013.05.003

De Leeuw J, Njenga M, Wagner B, Iiyama M (eds) (2013) Treesilience, an assessment of the resilience provided by trees in the dry lands of Eastern Africa. World Agroforestry Center, Nairobi 
de Souza HN, de Goede RG, Brussaard L, Cardoso IM, Duarte EM, Fernandes RB, Gomes LC, Pulleman MM (2012) Protective shade, tree diversity and soil properties in coffee agroforestry systems in the Atlantic Rainforest biome. Agric Ecosyst Environ 146(1):179-196

de Sousa K, van Zonneveld M, Holmgren M, Kindt R, Ordoñez JC (2019) The future of coffee and cocoa agroforestry in a warmer Mesoamerica. Sci Rep 9(1):p8828

de Zoysa M, Inoue M (2014) Climate change impacts, agroforestry adaptation and policy environment in Sri Lanka. Open J Forestry 4(5):p439

DeClerk F, Le Coq JF, Rapidel B, Beer J (eds.) (2012) Ecosystem services from agriculture and agroforestry: measurement and payment. Routledge.

Deheuvels O, Avelino J, Somarriba E, Malezieux E (2012) Vegetation structure and productivity in cocoa-based agroforestry systems in Talamanca, Costa Rica. Agric Ecosyst Environ 149:181-188

Delgado JPM, Yuyama K, Cardenas JR (2016) Does a greater number of branches improve initial fruit production in camu-camu? A test under different types of plantation and cropping management. Fruits 71(1):35-40

Dempewolf H, Eastwood RJ, Guarino L, Khoury CK, Müller JV, Toll J (2014) Adapting agriculture to climate change: a global initiative to collect, conserve, and use crop wild relatives. Agro Ecol Sustain Food Syst 38(4):369-377

Den Herder M, Moreno G, Mosquera-Losada RM, Palma JH, Sidiropoulou A, Freijanes JJS, CrousDuran J, Paulo JA, Tomé M, Pantera A, Papanastasis VP (2017) Current extent and stratification of agroforestry in the European Union. Agric Ecosyst Environ 241:121-132

Dewi S, van Noordwijk M, Zulkarnain MT, Dwiputra A, Prabhu R, Hyman G, Gitz V, Nasi R (2017) Tropical forest-transition landscapes: a portfolio for studying people, tree crops and agro-ecological change in context. Int J Biodivers Sci Ecosyst Serv Manag 13(1):312-329

Dietze MC, Sala A, Carbone MS, Czimczik CI, Mantooth JA, Richardson AD, Vargas R (2014) Nonstructural carbon in woody plants. Ann Rev Plant Biol 65:667-687

Do FC, Goudiaby VA, Gimenez O, Diagne AL, Diouf M, Rocheteau A, Akpo LE (2005) Environmental influence on canopy phenology in the dry tropics. For Ecol Man 215(1-3):319-328

Dow K, Berkhout F, Preston BL, Klein RJ, Midgley G, Shaw MR (2013) Limits to adaptation. Nature. Clim Change 3(4):305-307

Duguma LA, Minang PA, van Noordwijk M (2014) Climate change mitigation and adaptation in the land use sector: from complementarity to synergy. Env Manag 54(3):420-432

Dupraz C, Blitz-Frayret C, Lecomte I, Molto Q, Reyes F, Gosme M (2018) Influence of latitude on the light availability for intercrops in an agroforestry alley-cropping system. Agrofor Syst 92(4):1019-1033

Dupraz C, Wolz KJ, Lecomte I, Talbot G, Vincent G, Mulia R, Bussière F, Ozier-Lafontaine H et al (2019) Hi-sAFe: a 3D agroforestry model for integrating dynamic tree-crop interactions. Sustainability 11(8):p2293

Ellison D, Morris CE, Locatelli B, Sheil D, Cohen J, Murdiyarso D, Gutierrez V, Van Noordwijk M, Creed IF, Pokorny J, Gaveau D (2017) Trees, forests and water: cool insights for a hot world. Global Environ Change 43:51-61

Ellison D, Wang-Erlandsson L, van der Ent R, van Noordwijk M (2019) Upwind forests: managing moisture recycling for nature-based resilience. Unasylva 251:14-26

Fischer G, Shah MM, van Velthuizen HT (2002) Climate change and agricultural vulnerability. IIASA, Laxenburg

Fischer G, Shah M, Tubiello N, F, van Velhuizen H, (2005) Socio-economic and climate change impacts on agriculture: an integrated assessment, 1990-2080. Phil Trans Roy Soc B Biol Sci 360(1463):2067-2083

Forrester DI (2014) A stand-level light interception model for horizontally and vertically heterogeneous canopies. Ecol Model 276:14-22

Gaisberger H, Kindt R, Loo J, Schmidt M, Bognounou F, Da SS, Diallo OB, Ganaba S, Gnoumou A, Lompo D, Lykke AM (2017) Spatially explicit multi-threat assessment of food tree species in Burkina Faso a fine-scale approach. PloS One 12(9):e0184457

Glover N, Beer J (1986) Nutrient cycling in two traditional Central American agroforestry systems. Agrofor Syst 4(2):77-87

Goldschmidt EE (2013) The evolution of fruit tree productivity: a review. Econ Bot 67(1):51-62

Gomes LC, Bianchi FJJA, Cardoso IM, Fernandes RBA, Filho EIF, Schulte RPO (2020) Agroforestry systems can mitigate the impacts of climate change on coffee production: a spatially explicit assessment in Brazil. Agric Ecosyst Environ 294:106858. https://doi.org/10.1016/j.agee.2020.106858 
Gram G, Vaast P, van der Wolf J, Jassogne L (2018) Local tree knowledge can fast-track agroforestry recommendations for coffee smallholders along a climate gradient in Mount Elgon. Uganda Agroforest Syst 92(6):1625-1638

Groover AT (2005) What genes make a tree a tree? Trends Plant Sci 10(5):210-214

Guo L, Dai J, Wang M, Xu J, Luedeling E (2015) Responses of spring phenology in temperate zone trees to climate warming: a case study of apricot flowering in China. Agric For Meteorol 201:1-7

Haggar JP, Beer JW (1993) Effect on maize growth of the interaction between increased nitrogen availability and competition with trees in alley cropping. Agrofor Syst 21(3):239-249

Haggar JP, Tanner EVJ, Beer JW, Kass DCL (1993) Nitrogen dynamics of tropical agroforestry and annual cropping systems. Soil Biol Biochem 25(10):1363-1378

Hairiah K, van Noordwijk M, Sari RR, Saputra DD, Suprayogo D, Kurniawan S, Prayogo C, Gusli S (2020) A soil carbon stocks in Indonesian (agro) forest transitions Compaction conceals lower carbon concentrations in standard accounting. Agric Ecosyst Environ 294:106879. https://doi.org/ 10.1016/j.agee.2020.106879

Hairiah K, Widianto W, Suprayogo D, van Noordwijk M (2020) Tree roots anchoring and binding soil reducing landslide risk in Indonesian agroforestry. Land 9(8):256

Harja D, Vincent G, Mulia R, van Noordwijk M (2012) Tree shape plasticity in relation to crown exposure. Trees 26(4):1275-1285

Harmand JM, Avila H, Dambrine E, Skiba U, De Miguel S, Renderos RV, Oliver R, Jiménez F, Beer J (2007) Nitrogen dynamics and soil nitrate retention in a Coffea arabica-Eucalyptus deglupta agroforestry system in Southern Costa Rica. Biogeochemistry 85(2):125-139

Harrison MN, Jackson JK (1958) Ecological classification of the vegetation of the Sudan. Forests Bulletin Sudan 1958(2):45

Harrison RD, Thierfelder C, Baudron F, Chinwada P, Midega C, Schaffner U et al (2019) Agro-ecological options for fall armyworm (Spodoptera frugiperda JE Smith) management: providing low-cost, smallholder friendly solutions to an invasive pest. J Environ Manag 243:318-330

Heide OM (2008) Interaction of photoperiod and temperature in the control of growth and dormancy of Prunus species. Sci Hortic 115:309-314

HLPE (2019) Agroecological and other innovative approaches for sustainable agriculture and food systems that enhance food security and nutrition. A report by the high level panel of experts on food security and nutrition of the committee on world food security, Rome.

Hoang MH, Namirembe S, van Noordwijk M, Catacutan D, Öborn I, Perez-Teran AS, Nguyen HQ, DumasJohansen MK (2014) Farmer portfolios, strategic diversity management and climate-change adaptation-implications for policy in Vietnam and Kenya. Clim Dev 6(3):216-225

Huxley PA (1965) A simple method for displaying diurnal patterns of cloudiness with some examples from East Africa. Agric Meteorol 2(1):17-25

Huxley PA (1980) Agroforestry - developing a new research discipline. In: Buck L (ed) Proceedings of the Kenya National Seminar on Agroforestry, 12-22 Nov 1980 ICRAF, University of Nairobi Nairobi, Kenya. pp 55-68

Huxley PA (1983) Phenology of woody perennials and annual crops with reference to their management in agroforestry systems. In: Huxley PA (ed) Plant Research and Agroforestry. ICRAF, Nairobi, pp 503-525

Huxley PA (1985a) The treecrop interface or simplifying the biological/environmental study of mixed cropping agroforestry systems. Agrofor Syst 3:251-266

Huxley PA (1985b) The basis of selection, management and evaluation of multipurpose trees: an overview. In: Cannell, MGR \& Jackson, JE (eds) Attributes of Trees as Crop Plants Institute of Terrestrial Ecology, Abbots Ripton, pp 13-35.

Huxley PA (1985c) Experimental agroforestry progress through perception and collaboration? Agroforest Syst 3:129-138

Huxley PA (1987) Agroforestry experimentation: separating the wood from the trees? Agroforest Syst 5(3):251-275

Huxley PA (1989) Some biological research considerations for sustainability arising from the objectives and characteristics of landuse systems. In: Viewpoints and issues on agroforestry and sustainability. ICRAF, Nairobi.

Huxley PA (1994) Root systems of some tree species and implications for resource capture in agroforestry. In: Monteith, JI, Scott, RK \& Unsworth, MH (eds) Resource capture by crops Proceedings of the 52nd Easter School in Agricultural Sciences. Nottingham University Press, Nottingham, pp 409-410.

Huxley PA (1995) An agroforestry sustainability framework: part 1, introduction. Draft document prepared for FAO's Agroforestry Sub-Group FAO, Rome, pp 120. 
Huxley PA (1996) Biological factors affecting form and function in woody/non-woody plant mixtures. In: Ong CK, Huxley PA (eds) Tree crop interactions: a physiological Approach. CAB International/ ICRAF, Wallingford/Nairobi, pp 235-298

Huxley PA (1999)a Tropical agroforestry. Blackwell Science, Oxford.

Huxley PA (1999) Multipurpose trees biological and ecological aspects relevant to their selection and use. In: Last F (ed) Tree Crop Ecosystems. Elsevier, Amsterdam

Huxley PA, Beadle M (1964) A local climatic study in typical dissected topography in the southern region of Uganda. Meteorol Mag 93:321-333

Huxley PA, Greenland DJ (eds) (1989) Pest management in agroforestry systems: a record of discussions held at CAB International, Wallingford, 28-29 July 1988. Agroforestry Abstracts 2, 3746.

Huxley PA, Maingu Z (1978) Use of a systematic spacing design as an aid to the study of intercropping: some general considerations. Exp Agric 14:49-56

Huxley PA, Turk A (1975) Preliminary investigations with arabica coffee in a root observation laboratory in Kenya. Kenya Coffee 41:349-360 Also in East African Agriculture and Forestry Journal 40:300-312.

Huxley PA, Mead R (1988) An ecological approach to on-farm experimentation. ICRAF Working Paper No 52. ICRAF, Nairobi.

Huxley PA, Van Eck WA (1974) Seasonal changes in growth and development of some woody perennials near Kampala. J Ecol 62:579-592

Huxley PA, Westley SB (1989) Multipurpose trees: selection and testing for agroforestry: multipurpose trees and shrubs for specified agroforestry technologies and land-use systems-the ICRAF approach. (No 63158 M961m). ICRAF, Nairobi.

Huxley PA, Patel RZ, Kabaara AM, Mitchell HW (1974) Tracer studies with 32P on the distribution of functional roots of arabica coffee in Kenya. Ann of App Biol 77:159-180

Huxley PA, Burley J, Wood PJ, Robinson PJ (1983) Methodology for the exploration and assessment of multipurpose trees (MPTS). International Council for Research in Agroforestry(ICRAF), Nairobi.

Huxley PA, Akunda E, Repollo A (1989) Climate and plant responses: the use of phenological data to help with the choice of woody species for agroforestry systems. In: Reifsnyder WS, Darnhofer TO (eds) Meteorology and agroforestry. ICRAF, Nairobi, pp 99-113

Huxley PA, Pinney A, Akunda E, Muraya P (1994) A tree/crop orientation experiment with a Grevillea robusta hedgerow and maize. Agroforest Syst 26:23-45.

Iiyama M, Derero A, Kelemu K, Muthuri CW, Kinuthia R, Ayenkulu E, Kiptot E, Hadgu K, Mowo J, Sinclair FL (2017) Understanding patterns of tree adoption on farms in semi- arid and sub- humid Ethiopia. Agroforest Syst 91:271-293

Ilstedt U, Tobella AB, Bazié HR, Bayala J, Verbeeten E, Nyberg G, Sanou J, Benegas L, Murdiyarso D, Laudon H, Sheil D (2016) Intermediate tree cover can maximize groundwater recharge in the seasonally dry tropics. Sci Rep 6, p21930.

Imbach AC, Fassbender HW, Borel R, Beer J, Bonmnemann A (1989) Modelling agroforestry systems of cacao (Theobroma cacao) with laurel (Cordia alliodora) and cacao with poro (Erythrina poeppigiana) in Costa Rica. Agrofor syst 8(3):267-287

International Council for Research in Agroforestry (1988) Proceedings of an ICRAF mini-workshop on experimental design, Nairobi, Kenya, 7-11 June 1988. (Ed J H Roger), Nairobi

IPCC (2019)

Isaac ME, Borden KA (2020) Nutrient acquisition strategies in agroforestry systems. Plant Soil https://doi. org/10.1007/s11104-019-04232-5

Izumi Y, Okaichi S, Awala SK, Kawato Y, Watanabe Y, Yamane K, Iijima M (2018) Water supply from pearl millet by hydraulic lift can mitigate drought stress and improve productivity of rice by the close mixed planting. Plant Prod Sci 21(1):8-15

Jackson JK (1957) Changes in the climate and vegetation of the Sudan. Sudan Notes and Records 38(47):66

Jamnadass R, Ofori DA, Dawson IK, Tchoundjeu Z, McMullin S, Hendre PS, Graudal L (2019) Enhancing agroforestry systems through tree domestication. In: van Noordwijk M (ed) Sustainable development through trees on farms: agroforestry in its fifth decade. World Agroforestry (ICRAF), Bogor, pp 45-59

Jerneck A, Olsson L (2013) More than trees! Understanding the agroforestry adoption gap in subsistence agriculture: insights from narrative walks in Kenya. J Rural Stud 32:114-125

Jerneck A, Olsson L (2014) Food first! Theorising assets and actors in agroforestry: risk evaders, opportunity seekers and 'the food imperative' in sub-Saharan Africa. Int J Agric Sustain 12(1):1-22

Jones M, Sinclair FL, Grime VL (1998) Effect of tree species and crown pruning on root length and soil water content in semi-arid agroforestry. Plant Soil 201:197-207

Jose S (2009) Agroforestry for ecosystem services and environmental benefits: an overview. Agrofor Syst 76(1):1-10 
Jose S, Bardhan S (2012) Agroforestry for biomass production and carbon sequestration: an overview. Agrofor Syst 86(2):105-111

Jose S, Dollinger J (2019) Silvopasture: a sustainable livestock production system. Agrofor syst 93(1):1-9

Jose S, Gordon AM (eds.) (2007) Toward agroforestry design: an ecological approach (Vol. 4). Springer, Dordrecht

Jose S, Gold MA, Garrett HE (2012) The future of temperate agroforestry in the United States. In: Nair PK, Garrity DPG (eds) Agroforestry-the future of global land use. Springer, Dordrecht, pp 217-245

Jose S, Walter D, Kumar BM (2019) Ecological considerations in sustainable silvopasture design and management. Agrofor Syst 93(1):317-331

Kass DCL, Somarriba E (1999) Traditional fallows in Latin America. Agrofor Syst 47(1-3):13-36

Kay S, Graves A, Palma JH, Moreno G, Roces-Díaz JV, Aviron S, Chouvardas D, Crous-Duran J, FerreiroDomínguez N, de Jalón SG, Măcicăşan V (2019) Agroforestry is paying off-economic evaluation of ecosystem services in European landscapes with and without agroforestry systems. Ecosyst Serv 36:100896

Keesman KJ, Graves A, van der Werf W, Burgess PJ, Palma J, Dupraz C, van Keulen H (2011) A system identification approach for developing and parameterising an agroforestry system model under constrained availability of data. Environ Model Softw 26(12):1540-1553

Khasanah NM, Perdana A, Rahmanullah A, Manurung G, Roshetko JM, van Noordwijk M (2015) Intercropping teak (Tectona grandis) and maize (Zea mays): bioeconomic trade-off analysis of agroforestry management practices in Gunungkidul. Agroforest Syst 89(6):1019-1033

Khasanah N, Van Noordwijk M, Slingerland M, Sofiyudin M, Stomph D, Migeon AF, Hairiah K (2020) Oil palm agroforestry can achieve economic and environmental gains as indicated by multifunctional Land Equivalent Ratios. Frontiers in Sustainable Food Systems 3:122

Kimaro AA, Sererya OG, Matata P, Uckert G, Hafner J, Graef F, Sieber S, Rosenstock TS (2019) Understanding the multidimensionality of climate-smartness: examples from agroforestry in Tanzania. The climate-smart agriculture papers. Springer, Cham, pp 153-162

Kindt R (2018) Ensemble species distribution modelling with transformed suitability values. Env Model Softw 100:136-145

Kizito F, Dragila MI, Senè M, Brooks JR, Meinzer FC, Diedhiou I, Diouf M, Lufafa A, Dick RP, Selker J, Cuenca R (2012) Hydraulic redistribution by two semi-arid shrub species: implications for Sahelian agro-ecosystems. J Arid Environ 83:69-77

Kmoch L, Pagella T, Palm M, Sinclair FL (2018) Using local agroecological knowledge in climate change adaptation: a study of tree-based options in Northern Morocco. Sustainability 10:p3719

Kumar BM (2008) Litter dynamics in plantation and agroforestry systems of the tropics-a review of observations and methods. In: Batish DR, Kohli RK, Jose S, Singh HP (eds) Ecological basis of agroforestry. CRC Press, Boca Raton, Fl (USA), pp 181-216

Kumar BM, Jose S (2018) Phenotypic plasticity of roots in mixed tree species agroforestry systems: review with examples from peninsular India. Agrofor syst 92(1):59-69

Kumar BM, Nair PKR (2011) Carbon sequestration potential of agroforestry systems - opportunities and challenges. Springer, Berlin

Kuyah S, Whitney CW, Jonsson M, Sileshi GW, Öborn I, Muthuri CW, Luedeling E (2019) Agroforestry delivers a win-win solution for ecosystem services in sub-Saharan Africa: a meta-analysis. Agron Sustain Dev 39:p47

Kuyper TW, Cardoso IM, Onguene NA, Murniati, van Noordwijk M, (2004) Managing mycorrhiza in tropical multispecies agroecosystems. In: van Noordwijk M, Cadisch G, Ong CK (eds) Belowground interactions in tropical agroecosystems. CAB International, Wallingford, pp 243-261

Lanza K, Stone B (2016) Climate adaptation in cities: what trees are suitable for urban heat management? Landsc Urban Plan 153:74-82

Lasco RD, Delfino RJP, Espaldon MLO (2014) Agroforest systems helping smallholders adapt to climate risks while mitigating climate change. Wiley Interdisciplin Rev Clim Change 5(6):825-833

Lasco RD, Delfino RJP, Catacutan DC, Simelton ES, Wilson DM (2014) Climate risk adaptation by smallholder farmers the roles of trees and agroforestry. Curr Opin Env Sust 6:83-88

Lasco RD, Espaldon MLO, Habito CMD (2016) Smallholder farmers' perceptions of climate change and the roles of trees and agroforestry in climate risk adaptation: evidence from Bohol. Philippines Agroforest Syst 90(3):521-540

Linkosalo T, Häkkinen R, Hänninen H (2006) Models of the spring phenology of boreal and temperate trees: is there something missing? Tree Physiol 26:1165-1172

Liu J, Sherif SM (2019) Hormonal orchestration of bud dormancy cycle in deciduous woody perennials. Front Plant Sci 10:p1136 
Lovell ST, Dupraz C, Gold M, Jose S, Revord R, Stanek E, Wolz KJ (2018) Temperate agroforestry research: considering multifunctional woody polycultures and the design of long-term field trials. Agrofor Syst 92(5):1397-1415

Lu Y, Ranjitkar S, Harrison RD, Xu J, Ou X, Ma X, He J (2017) Selection of native tree species for subtropical forest restoration in Southwest China. PloS One 12(1):e0170418

Luedeling E (2012) Climate change impacts on winter chill for temperate fruit and nut production: a review. Sci Hortic 144:218-229

Luedeling E, Brown PH (2011) A global analysis of the comparability of winter chill models for fruit and nut trees. Int J Biometeorol 55:411-421

Luedeling E, Gassner A (2012) Partial least squares regression for analyzing walnut phenology in California. Agric For Meteorol 158-159:43-52

Luedeling E, Zhang M, Luedeling V, Girvetz EH (2009) Sensitivity of winter chill models for fruit and nut trees to climate change. Agric Ecosyst Environ 133:23-31

Luedeling E, Kindt R, Huth NI, Koenig K (2014) Agroforestry systems in a changing climate-challenges in projecting future performance. Curr Opin Environ Sust 6:1-7

Luedeling E, Smethurst PJ, Baudron F, Bayala J, Huth NI, van Noordwijk M, Ong CK, Mulia R, Lusiana B, Muthuri CW, Sinclair FL (2016) Field-scale modeling of tree-crop interactions: challenges and development needs. Agric Syst 142:51-69

Lundgren B, Nair PKR, van Noordwijk M, Ong CK, Sinclair FL, Coe R, Cooper P, Giller KE, Muthuri CW, Jose S (2020) In memoriam: Peter A Huxley (1926-2019). Agrofor syst 101007/ s10457-020-00490-w

Maranz S (2009) Tree mortality in the African Sahel indicates an anthropogenic ecosystem displaced by climate change. J Biogeogr 36(6):1181-1193

Marsden C, Martin-Chave A, Cortet J, Hedde M, Capowiez Y (2020) How agroforestry systems influence soil fauna and their functions-a review. Plant Soil 453(1):29-44

Mbow C, Smith P, Skole D, Bustamante Duguma L, M, (2014) Achieving mitigation and adaptation to climate change through sustainable agroforestry practices in Africa. Curr Opin Environ Sust 6:8-14

Mbow C, van Noordwijk M, Luedeling E, Neufeldt H, Minang PA, Kowero G (2014) Agroforestry solutions to address food security and climate change challenges in Africa. Curr Opin Env Sust 6:61-67

Mbow C, Brandt M, Ouedraogo I, De Leeuw J, Marshall M (2015) What four decades of earth observation tell us about land degradation in the Sahel? Rem Sens 7(4):4048-4067

McCarthy N, Lipper L, Branca G (2011). Climate-smart agriculture smallholder adoption and implications for climate change adaptation and mitigation. Mitigation of Climate Change in Agriculture Working Paper 3 1-37. FAO, Rome.

Meng J, Fan J, Ludescher J, Agarwal A, Chen X, Bunde A, Kurths J, Schellnhuber HJ (2020) Complexity-based approach for El Niño magnitude forecasting before the spring predictability barrier. Proc Nat Acad Sci 117(1):177-183. https://doi.org/10.1073/pnas 1917007117

Meybeck A, Gitz V, Wolf J, Wong T (2020) Addressing forestry and agroforestry in National Adaptation Plans. FTA and FAO, Bogor and Rome. https://doi.org/10.4060/cb1203en

Minasny B, McBratney AB (2018) Rejoinder to the comment on: B Minasny \& AB McBratney (2018) Limited effect of organic matter on soil available water capacity. Europ J Soil Sci 69(1):155-157

Mize CW, Brandle JR, Schoeneberger MM, Bentrup G (2008) Ecological development and function of shelterbelts in temperate North America. pp. 27-54. In: Toward Agroforestry Design. Springer, Dordrecht.

Mokria M, Gebrekirstos A, Abiyu A, van Noordwijk M, Bräuning A (2017) Multi-century tree-ring precipitation record reveals increasing frequency of extreme dry events in the upper Blue Nile River catchment. Glob Change Biol 23(12):5436-5454

Mora A, Beer J (2013) Geostatistical modeling of the spatial variability of coffee fine roots under Erythrina shade trees and contrasting soil management. Agrofor Syst 87(2):365-376

Morris CE, Conen F, Alex-Huffman J, Phillips V, Pöschl U, Sands DC (2014) Bioprecipitation: a feedback cycle linking Earth history, ecosystem dynamics and land use through biological ice nucleators in the atmosphere. Glob Change Biol 20(2):341-351

Mosquera-Losada MR, Moreno G, Pardini A, McAdam JH, Papanastasis V, Burgess PJ, Lamersdorf N, Castro M, Liagre F, Rigueiro-Rodríguez A (2012) Past, present and future of agroforestry systems in Europe pp. 285-312. in: Nair PKR, Garrity DPG (Eds.) Agroforestry - the future of global land use. Springer, Dordrecht, https://doi.org/10.1007/978-94-007-4676-3_16

Muchane MN, Sileshi GW, Jonsson M, Pumariño L, Barrios E (2020) Agroforestry boosts soil health in the humid and sub-humid tropics: a meta-analysis. Agric Ecosyst Environ 295:106899. https://doi. org/10.1016/j.agee.2020.106899 
Mulia R, Dupraz C, van Noordwijk M (2010) Reconciling root plasticity and architectural ground rules in tree root growth models with voxel automata. Plant Soil 337(1-2):77-92

Mulyoutami E, Lusiana B, van Noordwijk M (2020) Gendered migration and agroforestry in Indonesia: livelihoods, labor, know-how, networks. Land 9(12):529

Muthuri CW, Ong CK, Black CR, Mati BM, Ngumi VW, van-Noordwijk M, (2004) Modelling the effects of leafing phenology on growth and water use by selected agroforestry tree species in semiarid Kenya. Land Use Water Resour Res 4:1-11

Muthuri CW, Ong CK, Mati BM, Ngumi VW, Black CR (2009) Gas exchange and water use efficiency of trees and crops in agroforestry systems in semi-arid Kenya. Agric Ecosyst Environ 129:497-507

Nair PKR (1985) Classification of agroforestry systems. Agrofor Syst 3(2):97-128

Nair PKR (1993) An introduction to agroforestry. Kluwer Academic Publishers, Dordrecht, The Netherlands

Ndoli A, Baudron F, Sida TS, Schut AG, van Heerwaarden J, Giller KE (2018) Conservation agriculture with trees amplifies negative effects of reduced tillage on maize performance in East Africa. Field Crops Res 221:238-244

Nester MR (1994) HAHA designs. Australas J Comb 9:261-274

Newaj R, Chaturvedi OP, Handa AK (2016) Recent development in agroforestry research and its role in climate change adaptation and mitigation. Indian J Agrofor 18:1-9

Nguyen Q, Hoang MH, Öborn I, van Noordwijk M (2013) Multipurpose agroforestry as a climate change resiliency option for farmers: an example of local adaptation in Vietnam. Clim Change 117(1-2):241-257

Norgrove L (2018) Neither dark nor light but shades in-between: cocoa merits a finer sampling. Glob Change Biol 24:559-560

Noulèkoun F, Khamzina A, Naab JB, Khasanah N, van Noordwijk M, Lamers JPA (2018) Climate change sensitivity of multi-species afforestation in semi-arid Benin. Sustainability 10:p1931

Nyaga J, Muthuri CW, Barrios E, Öborn I, Sinclair FL (2019) Enhancing maize productivity in agroforestry systems through managing competition: lessons from smallholders' farms, Rift valley. Kenya Agrofor syst 93(2):715-730

Nygren P, Kiema P, Rebottaro S (1996) Canopy development, CO2 exchange and carbon balance of a modeled agroforestry tree. Tree Physiol 16(9):733-745

Nygren P, Leblanc HA (2015) Dinitrogen fixation by legume shade trees and direct transfer of fixed $\mathrm{N}$ to associated cacao in a tropical agroforestry system. Tree Physiol 35(2):134-147

Nyong A, Adesina F, Elasha BO (2007) The value of indigenous knowledge in climate change mitigation and adaptation strategies in the African Sahel. Mitig Adapt Strat Gl 12(5):787-797

Ogle SM, Wakelin SJ, Buendia L, McConkey B, Baldock J, Akiyama H, Kishimoto-Mo AW, Chirinda $\mathrm{N}$, et al. (2019) Cropland - Chapter 5, in: Volume 4 - Agriculture, forestry and other land use (2019) Refinement to the (2006) guidelines for national greenhouse gas inventories. IPCC, Hayama, Japan https://www.ipcc-nggip.iges.or.jp/public/2019rf/pdf/4_Volume4/19R_V4_Ch05_Cropl and.pdf

Ong CK, Black C, Wilson J (eds) (2015) Tree-crop interactions: agroforestry in a changing climate. CAB International, Wallingford

Ong CK, Huxley PA (eds) (1996) Tree-crop interactions: a physiological approach. CAB International/ ICRAF, Wallingford/Nairobi, p 386

Ordoñez JC, Luedeling E, Kindt R, Tata HL, Harja D, Jamnadass R, van Noordwijk M (2014) Constraints and opportunities for tree diversity management along the forest transition curve to achieve multifunctional agriculture. Curr Opin Env Sust 6:54-60

Ovalle-Rivera O, Läderach P, Bunn C, Obersteiner M, Schroth G (2015) Projected shifts in Coffea arabica suitability among major global producing regions due to climate change. PLoS ONE 10(4):e0124155

Pachauri RK, Allen MR, Barros VR, Broome J, Cramer W, Christ R, Church JA, Clarke L, Dahe Q, Dasgupta P, Dubash NK (2014) Climate change 2014: synthesis report. Contribution of Working Groups I, II and III to the fifth assessment report of the Intergovernmental Panel on Climate Change, IPCC, Geneva, pp 151.

Pandey R, Meena D, Aretano R, Satpathy S, Semeraro T, Gupta AK, Rawat S, Zurlini G (2015) Socio-ecological vulnerability of smallholders due to climate change in mountains: agroforestry as an adaptation measure. Change Adapt Socio-Ecol Syst 2:26-41. https://doi.org/10.1515/ cass-2015-0003

Pantera A, Burgess PJ, Losada RM, Moreno G, López-Díaz ML, Corroyer N, McAdam J, Rosati A, Papadopoulos AM, Graves A, Rodríguez AR (2018) Agroforestry for high value tree systems in Europe. Agrofor Syst 92(4):945-959 
Panwar A, Renner M, Kleidon A (2020) Imprints of evaporative conditions and vegetation type in diurnal temperature variations. Hydrol Earth Syst Sci 24(10):4923-4942

Park HI, Zo IS, Kim BY, Jee JB, Lee KT (2017) An analysis of global solar radiation using the GWNU solar radiation model and automated total cloud cover instrument in Gangneung region. J Korean Earth Sci Soc 38(2):129-140

Payan-Zelaya F, Harmand JM, Flores-Macías A, Beer J, Ramos-Espinoza G, de León GF (2013) Soil nutrient availability and $\mathrm{CO} 2$ production in agroforestry systems after the addition of Erythrina poeppigiana pruning residues and native microbial inocula. Agrofor Syst 87(2):439-450

Petit RJ, Hampe A (2006) Some evolutionary consequences of being a tree. Agrofor syst 37:187-214

Porter JR, Xie L, Challinor AJ, Cochrane K, Howden SM, Iqbal MM, Lobell DB, Travasso MI (2014) Food security and food production systems. In: Climate change 2014: impacts, adaptation, and vulnerability part A: global and sectoral aspects Contribution of Working Group II to the Fifth Assessment Report of the Intergovernmental Panel on Climate Change [Field, CB, Barros, VR, Dokken, DJ et al (eds)] Cambridge University Press, Cambridge, United Kingdom, pp 485-533.

Pramova E, Locatelli B, Djoudi H, Somorin OA (2012) Forests and trees for social adaptation to climate variability and change. Clim Change 3(6):581-596

Pretzsch H, Biber P, Uhl E, Dahlhausen J, Schütze G, Perkins D, Rötzer T, Caldentey J, Koike T, van Con T, Chavanne A (2017) Climate change accelerates growth of urban trees in metropolises worldwide. Sci Rep 7(1):p15403

Pretzsch H, Moser-Reischl A, Rahman MA, Pauleit S, Rötzer T (2021) Towards sustainable management of the stock and ecosystem services of urban trees. From theory to model and application. Trees, https://link.springer.com/article/https://doi.org/10.1007/s00468-021-02100-3

Quandt A, Neufeldt H, McCabe JT (2019) Building livelihood resilience: what role does agroforestry play? Clim Dev 11(6):485-500

Quesada F, Somarriba E, Vargas E (1989) Simulation of tree shadows in agroforestry systems. In: Reifsnyder WS, Darnhofer TO (eds) Meteorology and Agroforestry. ICRAF, Nairobi, pp 157-161

Rahn E, Läderach P, Baca M, Cressy C, Schroth G, Malin D, van Rikxoort H, Shriver J (2014) Climate change adaptation, mitigation and livelihood benefits in coffee production: where are the synergies? Mitig Adapt Strat Gl 19(8):1119-1137

Rahn E, Vaast P, Läderach P, van Asten P, Jassogne L, Ghazoul J (2018) Exploring adaptation strategies of coffee production to climate change using a process-based model. Ecol Mod 371:76-89

Rana SK, Rana HK, Shrestha KK, Sujakhu S, Ranjitkar S (2018) Determining bioclimatic space of Himalayan alder for agroforestry systems in Nepal. Plant Div 40(1):1-18

Ranjitkar S, Luedeling E, Shrestha KK, Guan K, Xu J (2013) Flowering phenology of tree rhododendron along an elevation gradient in two sites in the Eastern Himalayas. Int J Biomet 57:225-240

Ranjitkar S, Sujakhu NM, Lu Y, Wang Q, Wang M, He J, Mortimer PE, Xu J, Kindt R, Zomer RJ (2016) Climate modelling for agroforestry species selection in Yunnan Province, China. Env Mod Softw 75:263-272

Rao MK, Muraya P, Huxley PA (1993) Observations of some tree root systems in agroforestry intercrop situations and their graphical representation. Exp Agric 29:183-194

Reid R, Ferguson IS (1992) Development and validation of a simple approach to modelling tree shading in agroforestry systems. Agrofor Syst 20(3):243-252

Rinne PLH, Paul LK, van der Schoot C (2018) Decoupling photo- and thermoperiod by projected climate change perturbs bud development, dormancy establishment and vernalization in the model tree Populus. BMC Plant Biol 18:p220

Rios G, Leida C, Conejero A, Badenes ML (2014) Epigenetic regulation of bud dormancy events in perennial plant. Front Plant Sci 5:p6

Rippke U, Ramirez-Villegas J, Jarvis A, Vermeulen SJ, Parker L, Mer F, Diekkrüger B, Challinor AJ, Howden M (2016) Timescales of transformational climate change adaptation in sub-Saharan African agriculture. Nat Clim Change 6(6):p605

Robiglio V, Baca M, Donovan J, Bunn C, Reyes M, Gonzáles D, Sánchez C (2017) Impacto del cambio climático sobre la cadena de valor del café en el Perú. ICRAF Oficina Regional para América Latina, Lima, Perú

Roe S, Lawrence D, Streck C, Obersteiner M, Frank S, Griscom B, Gusti M, Harris N, Hausfather Z, Havlík P, House J, Nabuurs G-J, Sánchez MJS, Sanderman J, Smith P (2019) Contribution of the land sector to a $1.5^{\circ} \mathrm{C}$ world. Nat Clim Change 9:817-828. https://doi.org/10.1038/s41558-019-0591-9

Roger J, Muraya P (1991) Datachain: database of experimental data. ICRAF, Nairobi, p 172

Rosenstock TS, Dawson IK, Aynekulu E, Chomba S, Degrande A, Fornace K, Jamnadass R, Kimaro A, Kindt R, Lamanna C, Malesu M (2019) A planetary health perspective on agroforestry in Sub-Saharan Africa. One Earth 1(3):330-344 
Rosenstock TS, Lamanna C, Namoi N, Arslan A, Richards M (2019)b What is the evidence base for climate-smart agriculture in East and Southern Africa? A systematic map. In: The Climate-Smart Agriculture Papers. Springer, Cham. pp 141-151

Rosenstock TS, Wilkes A, Jallo C, Namoi N, Bulusu M, Suber M, Mboi D, Mulia R, Simelton E, Richards M, Gurwick N, Wollenberg E (2019) Making trees count measurement and reporting of agroforestry in UNFCCC national communications of non-Annex I countries. Agric Ecosyst Environ 284:106569. https://doi.org/10.1016/j.agee.2019.106569

Rosskopf E, Morhart C, Nahm M (2017) Modelling shadow using 3D tree models in high spatial and temporal resolution. Remote Sensing 9(7):719

Roupsard O, Ferhi A, Granier A, Pallo F, Depommier D, Mallet B, Joly H, Dreyer E (1999) Reverse phenology and dry-season water uptake by Faidherbia albida (Del) A Chev in an agroforestry parkland of Sudanese west Africa. Funct Ecol 13:460-472

Roupsard O, Audebert A, Ndour AP, Clermont-Dauphin C, Sanou AY, J, Koala J, Faye E, Sambakhe D, Jourdan C, Le Maire G, (2020) How far does the tree affect the crop in agroforestry? New spatial analysis methods in a Faidherbia parkland. Agric Ecosyst Environ 296:106928

Rowe EC, Hairiah K, Giller KE, van Noordwijk M, Cadisch G (1998) Testing the safety-net role of hedgerow tree roots by $15 \mathrm{~N}$ placement at different soil depths. Agrofor Syst 43:81-93. https://doi.org/10. 1023/A:1022123020738

Roy MM, Tewari JC, Ram M (2011) Agroforestry for climate change adaptations and livelihood improvement in Indian hot arid regions. Int J Agric Crop Sci 3(2):43-54

Sanogo K, Bayala J, Villamor GB, Dodiomon S, van Noordwijk M (2021) A non-destructive method for estimating woody biomass and carbon stocks of Vitellaria paradoxa in southern Mali, West Africa. Agrofor syst 95:135-150. https://doi.org/10.1007/s10457-020-00578-3

Saputra DD, Sari RR, Hairiah K, Roshetko JM, Suprayogo D, van Noordwijk M (2020) Can cocoa agroforestry restore degraded soil structure following conversion from forest to agricultural use? Agrofor Syst 94(6):2261-2276

Sari RR, Saputra DD, Hairiah K, Rozendaal D, Roshetko JM, van Noordwijk M (2020) Gendered species preferences link tree diversity and carbon stocks in cacao agroforest in Southeast Sulawesi. Indonesia Land 9(4):108

Schmidhuber J, Tubiello FN (2007) Global food security under climate change. Proc Nat Acad Sci 104(50):19703-19708

Schoeneberger M, Bentrup G, de Gooijer H, Soolanayakanahally R, Sauer T, Brandle J, Zhou X, Current D (2012) Branching out: agroforestry as a climate change mitigation and adaptation tool for agriculture. J Soil Water Conserv 67:128A-136A. https://doi.org/10.2489/jswc.67.5.128A

Schroth G, Jeusset A, Gomes A, Florence CT, Coelho NAP, Faria D, Läderach P (2016) Climate friendliness of cocoa agroforests is compatible with productivity increase. Mitig Adapt Strateg Glob Change 21:67-80. https://doi.org/10.1007/s11027-014-9570-7

Schwartz MD (1999) Advancing to full bloom: planning phenological research for the 21 st century. Int J Biomet 42:113-118

Sheil D, Murdiyarso DM (2009) How forests attract rain: an examination of a new hypothesis. BioSci 59(4):341-347

Shi L, Feng W, Xu J, Kuzyakov Y (2018) Agroforestry systems: meta-analysis of soil carbon stocks, sequestration processes, and future potentials. Land Degrad Dev 29:3886-3897. https://doi.org/10. 1002/ldr.3136

Sida TS, Baudron F, Kim H, Giller KE (2018) Climate-smart agroforestry: Faidherbia albida trees buffer wheat against climatic extremes in the central rift valley of Ethiopia. Agric For Meteorol 248:339-347

Simelton E, Viet Dam B, Catacutan DC (2015) Trees and agroforestry for coping with extreme weather events: experiences from northern and central Viet Nam. Agrofor Syst 89:1065-1082

Sinclair FL (1996) The emergence of associative tree ideotypes from ecophysiological research and farmers' knowledge. Agrofor Forum 7(4):17-19

Sinclair FL (1999) A general classification of agroforestry practice. Agrofor syst 46:161-180

Sinclair FL, Coe R (2019) The options by context approach: a paradigm shift in agronomy. Exp Agric 55(S1):1-13

Sinclair FL, Wezel A, Mbow C, Robiglio V, Harrison R, Chomba C (2019) The contribution of agroecological approaches to realizing climate-resilient agriculture. Background Paper Global Commission on Adaptation Rotterdam.

Smethurst PJ, Huth NI, Masikati P, Sileshi GW, Akinnifesi FK, Wilson J, Sinclair FL (2017) Accurate crop yield predictions from modelling tree-crop interactions in gliricidia-maize agroforestry. Agric Syst 155:70-77 
Smit B, Skinner MW (2002) Adaptation options in agriculture to climate change: a typology. Mitig Adapt Strat Gl 7(1):85-114

Smith P, Calvin K, Nkem J, Campbell D, Cherubini F, Grassi G, Korotkov V, Le Hoang A et al (2019) Which practices co-deliver food security, climate change mitigation and adaptation, and combat land-degradation and desertification? Glob Change Biol, gcb14878 101111/gcb14878

Smith-Dumont E, Bonhomme S, Pagella TF, Sinclair FL (2019) Structured stakeholder engagement leads to development of more diverse and inclusive agroforestry options. Exp Agric 55(S1):252-274

Somarriba E, Beer J (2011) Productivity of Theobroma cacao agroforestry systems with timber or legume service shade trees. Agrofor Syst 81(2):109-121

Somarriba E, Beer J, Muschler RG (2001) Research methods for multistrata agroforestry systems with coffee and cacao: recommendations from two decades of research at CATIE. Agrofor Syst 53(2):195-203

Somarriba E, Beer J, Alegre-Orihuela J, Andrade HJ, Cerda R, DeClerck F, Detlefsen G, Escalante M, Giraldo LA, Ibrahim M, Krishnamurthy L (2012) Mainstreaming agroforestry in Latin America. In: Nair PKR, Garrity DPG (eds) Agroforestry-the future of global land use. Springer, Dordrecht, pp 429-453

Somarriba E, Suárez-Islas A, Calero-Borge W, Villota A, Castillo C, Vílchez S, Deheuvels O, Cerda R (2014) Cocoa-timber agroforestry systems: theobroma cacao-Cordia alliodora in Central America. Agrofor Syst 88(6):1001-1019

Stigter CJ (2007) From basic agrometeorological science to agrometeorological services and information for agricultural decision makers: a simple conceptual and diagnostic framework. Agric For Meteorol 142:91-95

Stigter CJ (2016) A decade of capacity building through roving seminars on agro-meteorology/-climatology in Africa, Asia and Latin America: from agrometeorological services via climate change to agroforestry and other climate-smart agricultural practices. Implementing Climate Change Adaptation in Cities and Communities. Springer, Cham, pp 237-251

Syampungani S, Chirwa PW, Akinnifesi FK, Ajayi OC (2010) The potential of using agroforestry as a winwin solution to climate change mitigation and adaptation and meeting food security challenges in Southern Africa. Agric J 5(2):80-88

Talbot G, Dupraz C (2012) Simple models for light competition within agroforestry discontinuous tree stands: are leaf clumpiness and light interception by woody parts relevant factors? Agrofor Syst 84(1):101-116

Terrer C, Phillips RP, Hungate BA, Rosende J, Pett-Ridge J, Craig M, van Groenigen KJ, Keenan TF et al (2021) A trade-off between plant and soil carbon storage under elevated $\mathrm{CO}_{2}$. Nature 591:599-603

Tewari JC, Ram M, Roy MM, Dagar JC (2014) Livelihood improvements and climate change adaptations through agroforestry in hot arid environments. Agroforestry systems in India: livelihood security \& ecosystem services. Springer, New Delhi, pp 155-183

Thorlakson T, Neufeldt H (2012) Reducing subsistence farmers' vulnerability to climate change: evaluating the potential contributions of agroforestry in western Kenya. Agric Food Sec 1(1):p15

Tscharntke T, Clough Y, Bhagwat SA, Buchori D, Faust H, Hertel D, Hölscher D, Juhrbandt J, Kessler M, Perfecto I, Scherber C (2011) Multifunctional shade-tree management in tropical agroforestry landscapes-a review. J App Ecol 48(3):619-629

Udawatta RP, Gantzer CJ, Jose S (2017) Agroforestry practices and soil ecosystem services. In: Al-Kaisi MM, Lowery B (eds) Soil health and intensification of agroecosytems. Academic Press, London (UK), pp 305-333

Vaast P, Somarriba E (2014) Trade-offs between crop intensification and ecosystem services: the role of agroforestry in cocoa cultivation. Agrofor Syst 88(6):947-956

Vaast P, Beer J, Harvey C, Harmand JH (2005) Environmental services of coffee agroforestry systems in Central America: a promising potential to improve the livelihoods of coffee farmers' communities. In: Wallace HA (Ed.), Integrated management of environmental services in human-dominated tropical landscapes, Inter-American Scientific Conference Series, CATIE, Turrialba, Costa Rica.

Vaast P, Harmand JM, Rapidel B, Jagoret P, Deheuvels O (2016) Coffee and cocoa production in agroforestry-a climate-smart agriculture model. Climate change and agriculture worldwide. Springer, Dordrecht, pp 209-224

Valdez-Hernández M, Andrade JL, Jackson PC, Rebolledo-Vieyra M (2010) Phenology of five tree species of a tropical dry forest in Yucatan, Mexico: effects of environmental and physiological factors. Plant Soil 329(1-2):155-171

Van der Ent RJ, Savenije HH, Schaefli B, Steele-Dunne SC (2010) Origin and fate of atmospheric moisture over continents. Water Resour Res 46:9 
Van der Ent RJ, Tuinenburg OA (2017) The residence time of water in the atmosphere revisited. Hydrol Earth Syst Sci 21(2):779-790

van Kanten R, Beer J (2005) Production and phenology of the fruit shrub Eugenia stipitata in agroforestry systems in Costa Rica. Agrofor Syst 64(3):203-209

van Kanten R, Schroth G, Beer J, Jiménez F (2005) Fine-root dynamics of coffee in association with two shade trees in Costa Rica. Agrofor Syst 63(3):247-261

van Noordwijk M (1984) Ecology textbook for the Sudan. Khartoum University Press, Khartoum

van Noordwijk M (1996) A simple model to quantify mulch and shade effects. In: Ong CK, Huxley PA (eds) Tree-crop interactions - a physiological approach. CAB International, Wallingford (UK), pp 51-72

van Noordwijk M (2018) Agroforestry as part of climate change response. IOP Conf Ser Earth Environ Sci 200(1):012002

van Noordwijk M (2019a) Sustainable development through trees on farms: agroforestry in its fifth decade. World Agroforestry (ICRAF), Bogor.

van Noordwijk M (2019b) Integrated natural resource management as pathway to poverty reduction: innovating practices institutions and policies. Agric Syst 172:60-71

van Noordwijk M (2019c) Small-island agroforestry in an era of climate change and sustainable development goals. In: van Noordwijk M (ed) Sustainable development through trees on farms: agroforestry in its fifth decade. World Agroforestry (ICRAF), Bogor, pp 233-247.

van Noordwijk M, De Willigen P (1987) Agricultural concepts of roots: from morphogenetic to functional equilibrium between root and shoot growth. Neth J Agric Sci 35:487-496

van Noordwijk M, Coe R (2019) Methods in agroforestry research across its three paradigms. In: van Noordwijk M (ed) Sustainable development through trees on farms: agroforestry in its fifth decade. World Agroforestry (ICRAF), Bogor, pp 379-402

van Noordwijk M, Mulia R (2002) Functional branch analysis as tool for fractal scaling above-and belowground trees for their additive and non-additive properties. Ecol Model 149(1-2):41-51

van Noordwijk M, Ong CK (1999) Can the ecosystem mimic hypotheses be applied to farms in African savannahs? Agrof Syst 45(1):131-158

van Noordwijk M, Dijksterhuis GH, van Keulen H (1994) Risk management in crop production and fertilizer use with uncertain rainfall; how many eggs in which baskets? Neth J Agric Sci 42(4):249-269

van Noordwijk M, Martikainen P, Bottner P, Cuevas E, Rouland C, Dhillion SS (1998) Global change and root function. Glob Change Biol 4(7):759-772

van Noordwijk M, Rahayu S, Williams SE, Hairiah K, Khasanah N, Schroth G (2004) Crop and tree root-system dynamics. In: van Noordwijk M, Cadisch G, Ong CK (eds) Belowground interactions in tropical agroecosystems. CAB International, Wallingford, pp 83-107

van Noordwijk M, Hoang MH, Neufeldt H, Öborn I, Yatich T (2011a) How trees and people can coadapt to climate change: reducing vulnerability through multifunctional agroforestry landscapes. World Agroforestry Centre (ICRAF), Nairobi, pp 136.

van Noordwijk M, Lusiana B, Khasanah N, Mulia R (2011b) WaNuLCAS version 4.0, Background on a model of water nutrient and light capture in agroforestry systems. World Agroforestry Centre (ICRAF), Bogor.

van Noordwijk M, Bayala J, Hairiah K (2013) Climate: using local tree influences (CooLTree). In: van Noordwijk M, Lusiana B, Leimona B, Dewi S, Wulandari D (eds) Negotiation-support toolkit for learning landscapes. World Agroforestry Centre (ICRAF), Bogor, pp 80-82

van Noordwijk M, Bayala J, Hairiah K, Lusiana B, Muthuri CW, Khasanah N, Mulia R (2014) Agroforestry solutions for buffering climate variability and adapting to change. In: Fuhrer J, Gregory PJ (eds) Climate change impact and adaptation in agricultural systems. CAB-International, Wallingford (UK), pp 216-232

van Noordwijk M, Bruijnzeel LA, Ellison D, Sheil D, Morris CE, Gutierrez V, Cohen J, Sullivan CA, Verbist B, Muys B (2015)a Ecological rainfall infrastructure: investment in trees for sustainable development. ASB PolicyBrief 47. ASB Partnership for the Tropical Forest Margins World Agroforestry Centre (ICRAF), Nairobi, 6p.

van Noordwijk M, Lawson G, Hairiah K, Wilson J (2015)b Root distribution of trees and crops: competition and/or complementarity tree-crop interactions. In: Agroforestry in a changing climate CABI, Wallingford, pp 221-257.

van Noordwijk M, Kim YS, Leimona B, Hairiah K, Fisher LA (2016) Metrics of water security, adaptive capacity, and agroforestry in Indonesia. Curr Opin Environ Sust 21:1-8

van Noordwijk M, Duguma LA, Dewi S, Leimona B, Catacutan DC, Lusiana B, Öborn I, Hairiah K, Minang PA (2018) SDG synergy between agriculture and forestry in the food, energy, water and income nexus: reinventing agroforestry? Curr Opin Environ Sust 34:33-42 
van Noordwijk M, Rahayu S, Gebrekirstos A, Kindt R, Tata HL, Muchugi A, Ordonez JC, Xu J (2019a) Tree diversity as basis of agroforestry. In: van Noordwijk M (Ed.) Sustainable development through trees on farms: agroforestry in its fifth decade. World Agroforestry (ICRAF), Bogor, Indonesia. pp 17-44,

van Noordwijk M, Zomer RJ, Xu J, Bayala J, Dewi S, Miccolis A, Cornelius J, Robiglio V, Nayak D, Rizvi J (2019b ) Agroforestry options, issues and progress in regional contexts. In: van Noordwijk M (ed) Sustainable development through trees on farms: agroforestry in its fifth decade. World Agroforestry (ICRAF), Bogor, pp 113-138.

van Noordwijk M, Bargues-Tobella A, Muthuri CW, Gebrekirstos A, Maimbo M, Leimona B, Bayala J, Ma X, Lasco R, Xu J, Ong CK (2019c) Agroforestry as part of nature-based water management. In: van Noordwijk M (ed) Sustainable development through trees on farms: agroforestry in its fifth decade. World Agroforestry (ICRAF), Bogor, pp 305-333.

van Noordwijk M, Duguma LA, Dewi S, Leimona B, Catacutan D, Lusiana B, Öborn I, Hairiah K, et al (2019d) Agroforestry into its fifth decade: local responses to global challenges and goals in the Anthropocene. In: van Noordwijk M (ed) Sustainable development through trees on farms: agroforestry in its fifth decade. World Agroforestry (ICRAF), Bogor, pp 405-428.

Vandermeer J, van Noordwijk M, Anderson J, Ong CK, Perfecto I (1998) Global change and multispecies agroecosystems: concepts and issues. Agric Ecosyst Environ 67(1):1-22

Varshney RK, Bansal KC, Aggarwal PK, Datta SK, Craufurd PQ (2011) Agricultural biotechnology for crop improvement in a variable climate: hope or hype? Trends Plant Sci 16(7):363-371

Verchot LV, van Noordwijk M, Kandji S, Tomich TP, Ong CK, Albrecht A, Palm CA (2007) Climate change: linking adaptation and mitigation through agroforestry. Mitig Adapt Strat G1 12:901-918

Vezy R, Christina M, Roupsard O, Nouvellon Y, Duursma R, Medlyn B, Soma M, Charbonnier F et al (2018) Measuring and modelling energy partitioning in canopies of varying complexity using MAESPA model. Agric For Meteorol 253:203-217

Wang X, Guo Y, Li B, Wang X, Ma Y (2006) Evaluating a three dimensional model of diffuse photosynthetically active radiation in maize canopies. Int J Biometeorol 50(6):349-357

Wang YP, Jarvis PG (1990) Description and validation of an array model - MAESTRO. Agric For Meteorol 51:257-280

Wanger TC, Hölscher D, Veldkamp E, Tscharntke TCocoa production: monocultures are not the solution to climate adaptation-response to Abdulai, et al (2018) Glob Change Biol 24:561-562

Wang-Erlandsson L, Fetzer I, Keys PW, Van der Ent RJ, Savenije HH, Gordon LJ (2018) Remote land use impacts on river flows through atmospheric teleconnections. Hydrol Earth Syst Sc 22(8):4311-4328

Wangpakapattanawong P, Finlayson R, Öborn I, Roshetko JM, Sinclair F, Shono K, Borelli S, Hillbrand A, Conigliaro M (2017) Agroforestry in rice-production landscapes in Southeast Asia: a practical manual. Food and Agriculture Organization of the United Nations Regional Office for Asia and the Pacific, Bangkok, Thailand.

Wanvestraut RH, Jose S, Nair PR, Brecke BJ (2004) Competition for water in a pecan (Carya illinoensis K. Koch)-cotton (Gossypium hirsutum L.) alley cropping system in the southern United States. Agrofor Syst 60(2):167-179

White F (1983) The vegetation of Africa, a descriptive memoir to accompany the UNESCO/AETFAT/ UNSO vegetation map of Africa. UNESCO, Natural Resour Res 20:1-356

Wojtkowski P (1998) The theory and practice of agroforestry design. A comprehensive study of the theories, concepts and conventions that underlie the successful use of agroforestry. Science Publishers, Inc.

Zamora DS, Jose S, Jones JW, Cropper WP (2009) Modeling cotton production response to shading in a pecan alleycropping system using CROPGRO. Agrofor Syst 76(2):423-435

Zhao W, Qualls RJ, Berliner PR (2003) Modeling of the short wave radiation distribution in an agroforestry system. Agric For Meteorol 118(3-4):185-206

Zhou XH, Brandle JR, Mize CW, Takle ES (2005) Three-dimensional aerodynamic structure of a tree shelterbelt: definition, characterization and working models. Agrofor Syst 63(2):133-147

Zomer RJ, Neufeldt H, Xu J, Ahrends A, Bossio D, Trabucco A, Van Noordwijk M, Wang M (2016) Global tree cover and biomass carbon on agricultural land: the contribution of agroforestry to global and national carbon budgets. Sci Rep 6:p29987

Publisher's note Springer Nature remains neutral with regard to jurisdictional claims in published maps and institutional affiliations. 


\section{Authors and Affiliations}

Meine van Noordwijk ${ }^{1,2}$ (D) $\cdot$ Richard Coe $^{1} \cdot$ Fergus L. Sinclair $^{1,3}$ (D) Eike Luedeling ${ }^{4}$. Jules Bayala ${ }^{1}$. Catherine W. Muthuri ${ }^{1}$ - Peter Cooper ${ }^{5} \cdot$ Roeland Kindt $^{1}$ (D) . Lalisa Duguma ${ }^{1} \cdot$ Christine Lamanna $^{1}$ - Peter A. Minang ${ }^{1}$

1 World Agroforestry (ICRAF), Nairobi, Kenya

2 Wageningen University, Wageningen, The Netherlands

3 Bangor University, Bangor, UK

4 University of Bonn, Bonn, Germany

5 Climate Change Food Security (CCAFS), Wageningen, The Netherlands 